\title{
Genomic determinants of PI3K pathway inhibitor response in cancer
}

\section{Britta Weigelt ${ }^{1}$ and Julian Downward ${ }^{1,2 *}$}

1 Signal Transduction Laboratory, Cancer Research UK London Research Institute, London, UK

2 Division of Cancer Biology, The Institute of Cancer Research, London, UK

\section{Edited by:}

Alexandre Arcaro, University of Bern, Switzerland

Reviewed by:

Edward Prochownik, University of Pittsburgh Medical Center, USA

Hua Yan, New York University School of Medicine, USA

\section{*Correspondence}

Julian Downward, Signal Transduction Laboratory, Cancer Research UK

London Research Institute, 44

Lincoln's Inn Fields, London WC2A

$3 L Y, U K$.

e-mail: julian.downward@

cancer.org.uk
The phosphoinositide 3-kinase (PI3K) pathway is frequently activated in cancer as a result of genetic (e.g., amplifications, mutations, deletions) and epigenetic (e.g., methylation, regulation by non-coding RNAs) aberrations targeting its key components. Several lines of evidence demonstrate that tumors from different anatomical sites depend on the continued activation of this pathway for the maintenance of their malignant phenotype. The PI3K pathway therefore is an attractive candidate for therapeutic intervention, and inhibitors targeting different components of this pathway are in various stages of clinical development. Burgeoning data suggest that the genomic features of a given tumor determine its response to targeted small molecule inhibitors. Importantly, alterations of different components of the PI3K pathway may result in distinct types of dependencies and response to specific therapeutic agents. In this review, we will focus on the genomic determinants of response to PI3K, dual PI3K/mechanistic target of rapamycin (mTOR), mTOR, and AKT inhibitors in cancer identified in preclinical models and clinical trials to date, and the development of molecular tools for the stratification of cancer patients.

\section{INTRODUCTION}

The phosphoinositide 3-kinase (PI3K) signaling pathway regulates numerous processes in the normal cell such as growth, proliferation, survival, motility, and metabolism (Engelman et al., 2006). In human cancer, the PI3K pathway is one of the most frequently activated signal transduction pathways, and its prominent role is highlighted by the array of mechanisms targeting several of its key components (Figure 1). Mutations and/or amplifications of genes encoding receptor tyrosine kinases (RTKs) upstream of class I PI3Ks (glossary box), including the human epidermal growth factor receptors EGFR (ERBB1) and HER2 (ERBB2), of the PI3K catalytic subunits $\mathrm{p} 110 \alpha(P I K 3 C A)$ and $\mathrm{p} 110 \beta(P I K 3 C B)$, the PI3K regulatory subunits $\mathrm{p} 85 \alpha$ (PIK3R1) and $\mathrm{p} 85 \beta$ (PIK3R2), the PI3K effector AKT (AKT1), and of the PI3K activator KRAS are frequently observed in cancer [Catalog Of Somatic Mutations In Cancer (COSMIC), http://www.sanger.ac.uk/cosmic; Forbes et al., 2011], as is loss of function of the tumor suppressors phosphatase and tensin homolog (PTEN) and inositol polyphosphate 4-phosphatase-II (INPP4B), negative regulators of PI3K signaling, through mutations, deletions, or epigenetic mechanisms (Gewinner et al., 2009; Fedele et al., 2010; Hollander et al., 2011).

Given that the PI3K pathway is frequently activated in cancers, that tumorigenesis and/or maintenance of the malignant phenotype of different tumor types is driven by its continued activation (Bader et al., 2005; Hollander et al., 2011), and that kinases are amendable to pharmacological intervention, it is not surprising that there has been great interest in the development of allosteric and ATP-competitive small molecule inhibitors targeting different components of this pathway downstream of RTKs (Liu et al., 2009). These targeted agents include PI3K inhibitors, either isoform specific [i.e., class I isoforms p110 $\alpha$, p110 $\beta$, p110 $\gamma$, p1108; (glossary box)] or pan-class I PI3K inhibitors, dual PI3K/mechanistic target of rapamycin (mTOR) inhibitors, mTOR inhibitors, and AKT inhibitors, which are all currently in various stages of clinical development (Table $\mathbf{1}$ ).

Over the past years it has become apparent that irrespective of the cancer type and small molecule inhibitor or antibody used, kinase inhibitor response is limited to those tumors whose proliferation and survival are reliant on the activation of the targeted oncogenic kinase (Sharma and Settleman, 2007; Janne et al., 2009). Bernard Weinstein coined the term "oncogene addiction" to describe this phenomenon (Weinstein, 2002), which has important implications for the targeting of kinases: given the incredibly diverse repertoire of genetic and epigenetic aberrations observed within a given cancer type, only the subset of tumors "addicted" to the continued activation of the oncogenic kinase targeted will prove vulnerable to the therapeutic intervention. Consistent with this "oncogene addiction" concept, strong associations between a tumor's genotype and its response to small molecule kinase inhibitors or antibodies targeting kinases have been identified. For example, melanomas harboring $B R A F^{\mathrm{V} 600 \mathrm{E}}$ mutations are selectively sensitive to the BRAF inhibitor Vemurafenib (Flaherty et al., 2010), non-small cell lung cancers (NSCLCs) harboring EGFR mutations to the EGFR inhibitors Gefitinib or Erlotinib (Pallis et al., 2011), HER2 amplified breast and gastric cancers to the HER2 targeting agents Trastuzumab or Lapatinib (Stern, 2012), and KIT and PDGFRA mutant gastrointestinal stromal tumors to Imanitib Mesylate and other small molecule inhibitors targeting mutant KIT and PDGFR $\alpha$ (Antonescu, 2011). Importantly, however, cancers harboring only wild-type copies of 


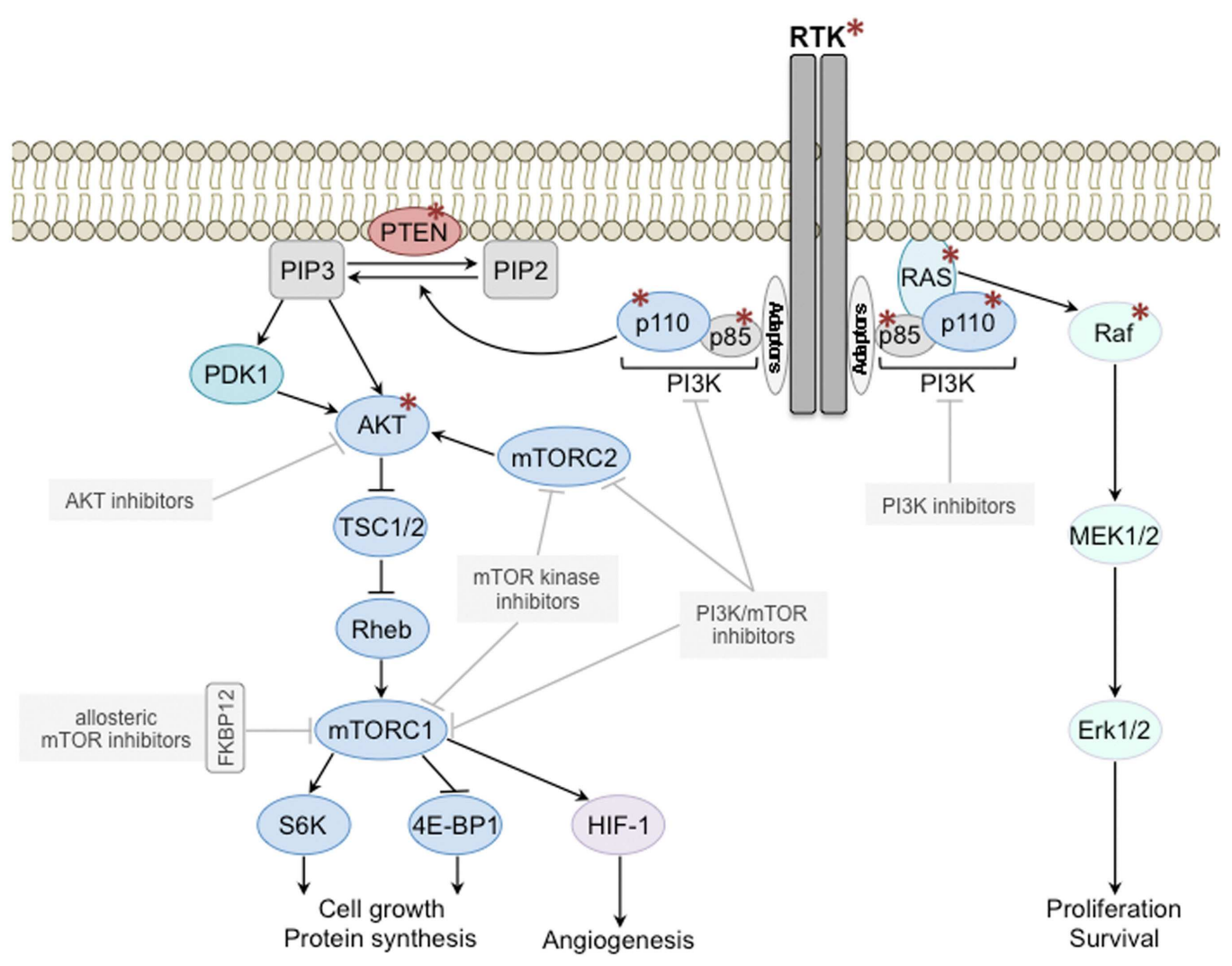

*Recurrent genetic (e.g. mutations, amplifications, deletions) and epigenetic (e.g. methylation) alterations

FIGURE 1 | Class I PI3K signal transduction pathway. Components of the class I PI3K signaling pathway (left) and of the mitogen-activated protein kinase (MAPK) pathway (right) recurrently targeted by genetic/epigenetic alterations in cancer are depicted with a red asterisk. Several PI3K pathway inhibitors downstream of RTKs are currently being tested in clinical trials (gray boxes). mTOR, mechanistic target of rapamycin; mTORC, mTOR complex; PI3K, phosphoinositide 3-kinase; PIP2, phosphatidylinositol 4,5-bisphosphate; PIP3, phosphatidylinositol $(3,4,5)$-triphosphate; PTEN, phosphatase and tensin homolog; RTK, receptor tyrosine kinase; TSC, tuberous sclerosis protein. the genes mentioned above seem not to be sensitive to the same agents.

As PI3K pathway inhibitors progress into trials focusing on their clinical efficacy (Table 1), it is critical to identify their genomic determinants of response and to select the patient population most likely to benefit from treatment. In fact, it has been suggested to incorporate predictive biomarkers throughout the clinical drug development process from phase I studies onward in order to enrich trials with patients more likely to respond to a given targeted therapy and to increase the chances of drug registration (Carden et al., 2010). For the guidance and prioritization of predictive biomarker candidates in early clinical trials, results derived from the study of preclinical models are of importance.

In this review, we focus on the genomic determinants of response to PI3K pathway inhibitors in cancer identified in preclinical models and clinical trials to date, and discuss the challenges for the development of molecular tools for the stratification of cancer patients.

\section{GENOMIC DETERMINANTS OF PI3K PATHWAY INHIBITOR RESPONSE IN PRECLINICAL MODELS}

The ease of therapeutic intervention using in vitro cell culture and the wealth of data available on the mutational landscape of known cancer genes in the most common cell lines obtainable from commercial repositories have made cancer cell line panels the model of choice for the preclinical study of drug response. Furthermore, with the advent of methods for massively parallel sequencing, it is now possible to identify the genomic determinants of therapy response in in vitro models in a genome-wide fashion (Barretina et al., 2012; Garnett et al., 2012). In general, sensitivity or resistance of cancer cell lines to a given targeted agent are determined by short-term treatment ranging from 48 to $120 \mathrm{~h}$ of cells grown on tissue culture plastic using several dilutions of the inhibitor. At the endpoint, cell number or cell viability is assessed and drug response reported as half-maximal inhibitory concentration $\left(\mathrm{IC}_{50}\right)$, or the concentration needed to reduce the growth of treated cells to half that of untreated or vehicle treated 
Table 1 | Open clinical trials testing PI3K pathway inhibitors in cancer*.

\begin{tabular}{|c|c|c|c|c|}
\hline Inhibitor name & Company & Target & $\begin{array}{l}\text { Clinical } \\
\text { trial phase }\end{array}$ & Cancer type \\
\hline \multicolumn{5}{|c|}{ PAN-CLASS I PI3K INHIBITORS } \\
\hline BAY80-6946 & Bayer & Class I PI3K & I & Advanced solid cancers \\
\hline ZSTK474 & Zenyaku Kogyo & Class I PI3K & I & Advanced solid cancers \\
\hline GSK1059615 & GlaxoSmithKline & Class I PI3K & I & Terminated \\
\hline BKM120 & Novartis & Class I PI3K & | and || & $\begin{array}{l}\text { (Advanced) solid cancers; NSCLC, endometrial, prostate, breast, } \\
\text { colorectal, pancreatic, renal cell, GIST, melanoma, glioblastoma, } \\
\text { leukemia, SCCHN, TCC }\end{array}$ \\
\hline GDC-0941 & Roche/Genentech & Class I PI3K & | and || & Solid cancers; breast, NSCLC, non-Hodgkin's Iymphoma \\
\hline PX866 & Oncothyreon & Class I PI3K & | and || & Prostate, NSCLC, SCCHN, colorectal, glioblastoma \\
\hline XL147 (SAR245408) & Exelixis/Sanofi-Aventis & Class I PI3K & | and || & Solid cancers; endometrial, ovarian, breast, NSCLC \\
\hline \multicolumn{5}{|c|}{ ISOFORM SPECIFIC PI3K INHIBITORS } \\
\hline BYL719 & Novartis & $\mathrm{p} 110 \alpha$ & I & Advanced solid cancers; SCCHN \\
\hline GDC-0032 & Roche/Genentech & $\mathrm{p} 110 \alpha$ & I & Solid cancers \\
\hline INK-1117 & Intellikine & $\mathrm{p} 110 \alpha$ & I & Advanced solid cancers \\
\hline GSK2636771 & GlaxoSmithKline & $\mathrm{p} 110 \beta$ & l/lla & Advanced solid cancers (PTEN deficient) \\
\hline IPI-145 & Infinity & $\mathrm{p} 110 \gamma, \mathrm{p} 110 \delta$ & I & Advanced hematological malignancies \\
\hline AMG319 & Amgen & p110 & I & Relapsed or refractory lymphoid malignancies \\
\hline CAL-101 (GS-1101) & Gilead sciences & p1108 & I, II, and III & $\begin{array}{l}\text { Chronic lymphocytic leukemia, Hodgkin lymphoma, non-Hodgkin's } \\
\text { lymphoma; mantle cell lymphoma, acute myeloid leukemia, } \\
\text { multiple myeloma }\end{array}$ \\
\hline \multicolumn{5}{|c|}{ DUAL PI3K/mTOR INHIBITORS } \\
\hline DS-7423 & Daiichi Sankyo & $\mathrm{PI3K} / \mathrm{mTOR}$ & 1 & Advanced solid cancers; colorectal, endometrial \\
\hline GDC-0980 & Roche/Genentech & $\mathrm{PI3K} / \mathrm{mTOR}$ & I & $\begin{array}{l}\text { (Advanced) solid cancers; non-Hodgkin's lymphoma, breast, } \\
\text { prostate, endometrial, renal cell }\end{array}$ \\
\hline GSK2126458 & GlaxoSmithKline & $\mathrm{PI3K} / \mathrm{mTOR}$ & 1 & Advanced solid cancers \\
\hline PWT33597 & Pathway Therapeutics & $\mathrm{PI3K} / \mathrm{mTOR}$ & 1 & Advanced solid cancers or malignant lymphoma \\
\hline SF1126 & Semafore & $\mathrm{PI3K} / \mathrm{mTOR}$ & I & Advanced solid cancers \\
\hline BEZ235 & Novartis & $\mathrm{PI3K} / \mathrm{mTOR}$ & | and || & Advanced solid cancers; renal cell, breast \\
\hline BGT226 & Novartis & $\mathrm{PI3K} / \mathrm{mTOR}$ & | and || & Completed (advanced solid cancers; breast) \\
\hline PF-04691502 & Pfizer & $\mathrm{PI3K} / \mathrm{mTOR}$ & | and || & Advanced solid cancers; breast, endometrial \\
\hline PF-05212384 (PKI-587) & Pfizer & $\mathrm{PI3K} / \mathrm{mTOR}$ & | and || & Advanced solid cancers; endometrial \\
\hline XL765 (SAR245409) & Exelixis/Sanofi-Aventis & $\mathrm{PI3K} / \mathrm{mTOR}$ & | and || & Advanced breast, gliomas, glioblastoma multiforme \\
\hline \multicolumn{5}{|c|}{ mTOR KINASE INHIBITORS } \\
\hline AZD2014 & AstraZeneca & mTOR & 1 & Advanced solid cancers; breast \\
\hline AZD8055 & AstraZeneca & mTOR & I & Recurrent glioma \\
\hline INK-128 & Intellikine & mTOR & I & $\begin{array}{l}\text { Advanced solid cancers; multiple myeloma, Waldenstrom } \\
\text { macroglobulinemia }\end{array}$ \\
\hline OSI-027 & Astellas Pharma & mTOR & I & Advanced solid cancers; lymphoma \\
\hline CC-223 & Celgene Corporation & mTOR & | and || & $\begin{array}{l}\text { Advanced solid cancers; non-Hodgkin's lymphoma, multiple } \\
\text { myeloma, NSCLC }\end{array}$ \\
\hline \multicolumn{5}{|c|}{ ALLOSTERIC mTOR INHIBITORS (RAPAMYCIN ANALOGS) } \\
\hline Sirolimus (Rapamycin) & Wyeth/Pfizer & mTOR & I, II, and III & $\begin{array}{l}\text { Advanced solid cancers; breast, liver, rectum, NSCLC, leukemias, } \\
\text { lymphomas, head and neck, pancreatic, ovarian, fallopian tube, } \\
\text { glioblastoma, fibromatosis }\end{array}$ \\
\hline Everolimus** (RAD001) & Novartis & mTOR & I, II, and III & $\begin{array}{l}\text { Solid cancers; leukemias, lymphomas, breast, bladder, head and } \\
\text { neck, kidney/renal cell, liver, gastric, thyroid, neuroendocrine } \\
\text { tumors, ovarian, fallopian tube, cervical, colorectal, brain and } \\
\text { central nervous system, prostate, endometrial, esophageal, } \\
\text { melanoma, NSCLC, SCLC, germ cell, soft tissue sarcoma, } \\
\text { osteosarcoma, nasopharyngeal, glioma, Waldenstrom's } \\
\text { macroglobulinemia }\end{array}$ \\
\hline
\end{tabular}


Table 1 | Continued

\begin{tabular}{|c|c|c|c|c|}
\hline Inhibitor name & Company & Target & $\begin{array}{l}\text { Clinical } \\
\text { trial phase }\end{array}$ & Cancer type \\
\hline Temsirolimus** (CCl-779) & Wyeth/Pfizer & mTOR & | and || & $\begin{array}{l}\text { Advanced solid cancers; breast, endometrial, ovarian, prostate, } \\
\text { liver, kidney/renal cell, SCCHN, NSCLC, melanoma, sarcoma, } \\
\text { lymphomas, leukemia, brain and central nervous system, bladder, } \\
\text { urethral }\end{array}$ \\
\hline Ridaforolimus (MK-8669) & Merck/Ariad & mTOR & I & $\begin{array}{l}\text { Advanced solid cancers; endometrial, ovarian, breast, NSCLC, } \\
\text { renal cell, soft tissue sarcoma }\end{array}$ \\
\hline \multicolumn{5}{|c|}{ AKT INHIBITORS (ATP-Competitive) } \\
\hline ARQ 092 & ArQule/Daiichi Sankyo & AKT & I & Advanced solid cancers \\
\hline AZD5363 & AstraZeneca & AKT & l & Advanced solid cancers \\
\hline GSK2141795 & GlaxoSmithKline & $\mathrm{AKT}$ & I & Completed/not recruiting (advanced solid cancers; Iymphoma) \\
\hline GDC-0068 & Roche/Genentech & AKT & | and || & Advanced solid cancers; prostate cancer \\
\hline GSK2110183 & GlaxoSmithKline & AKT & | and || & $\begin{array}{l}\text { Solid cancers, hematological malignancies, multiple myeloma, } \\
\text { Langerhans cell histiocytosis, chronic lymphocytic leukemia }\end{array}$ \\
\hline \multicolumn{5}{|c|}{ ALLOSTERIC AKT INHIBITORS } \\
\hline MK-2206 & Merck & AKT & | and || & $\begin{array}{l}\text { Advances solid cancers; breast, endometrial, ovarian, fallopian } \\
\text { tube, peritoneal, gastric, gastroesophageal junction, colorectal, } \\
\text { prostate, NSCLC, SCLC, melanoma, kidney, leukemias, } \\
\text { lymphomas, biliary, head and neck, liver, thymic, nasopharyngeal }\end{array}$ \\
\hline
\end{tabular}

${ }^{*}$ Data retrieved from http://clinicaltrials.gov and http://www.fda.gov/ (May 2012).

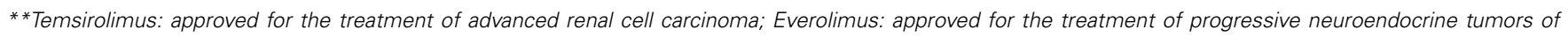
pancreatic origin, for advanced renal cell carcinoma after failure of treatment with sunitinib or sorafenib, for renal angiomyolipoma and tuberous sclerosis complex, and for subependymal giant cell astrocytoma associated with tuberous sclerosis.

GIST, gastrointestinal stromal tumor; NSCLC, non-small cell lung cancer; SCCHN, squamous cell carcinoma of the head and neck; SCLC, small cell lung cancer; TCC, transitional cell carcinoma of the urothelium.

cells $\left(\mathrm{GI}_{50}\right)$. In addition, xenograft studies in immunodeficient mice injected with human cancer cell lines or human tumor tissues, as well as transgenic mouse models have been employed to assess anti-tumor activity of PI3K pathway inhibitors in vivo using tumor growth, proliferation, apoptosis, and/or levels of pathway activation state as read-out of treatment response.

Using these preclinical approaches, several groups attempted to define genomic determinants of response to PI3K pathway inhibitors. It should perhaps not come as a surprise that genetic alterations leading to PI3K pathway activation, including PIK3CA gain-of-function mutations and/or PTEN mutations/PTEN loss of function and/or amplification of HER2, have been repeatedly identified as predictors of response to these agents (Table 2). However, tumor type-specific differences have been observed. For example, in ovarian cancer cells both PIK3CA mutations and PTEN deficiency have been reported to predict PI3K pathway inhibitor response (Ihle et al., 2009; Di Nicolantonio et al., 2010; Meuillet et al., 2010; Santiskulvong et al., 2011; Tanaka et al., 2011; Meric-Bernstam et al., 2012), whereas in breast cancer the associations between PTEN loss of function and response are less clear (She et al., 2008; Brachmann et al., 2009; Lehmann et al., 2011; Sanchez et al., 2011; Tanaka et al., 2011; Weigelt et al., 2011), which will be discussed in greater detail below.

Several studies provided evidence to suggest that cancer cells harboring PIK3CA gain-of-function mutations are selectively sensitive to inhibitors of different components of the PI3K pathway. In breast cancer, cell culture, and/or xenograft models identified
PIK3CA mutations as determinant of response to PI3K inhibition (O'Brien et al., 2010; Sanchez et al., 2011), dual PI3K/mTOR inhibition (Serra et al., 2008; Brachmann et al., 2009; Lehmann et al., 2011; Sanchez et al., 2011), mTOR kinase inhibition (Weigelt et al., 2011), allosteric mTOR inhibition (Sanchez et al., 2011; Weigelt et al., 2011), and AKT inhibition (She et al., 2008; Meuillet et al., 2010; Table 2). In one report, however, which assessed seven estrogen receptor (ER)-positive breast cancer cell lines and their response to the allosteric mTOR inhibitor Rapamycin (Sirolimus), no correlation with PIK3CA mutation status but to some extent with a $P I K 3 C A$ mutation associated gene signature was found (Loi et al., 2010). In vitro and xenograft models of breast cancer have also demonstrated that cells harboring amplification of the RTK HER2 are dependent on PI3K pathway activation and sensitive to its inhibition through targeting of PI3K (O'Brien et al., 2010; Tanaka et al., 2011), dual PI3K/mTOR (Brachmann et al., 2009), AKT (She et al., 2008), and mTOR kinase (Weigelt et al., 2011). In fact, mTOR kinase inhibitors seem to lead to a more effective decrease of PI3K pathway signaling than allosteric mTOR inhibitors given that HER2 amplified breast cancer cells in vitro have been found to be unresponsive to the rapamycin ana$\log$ ("rapalog") Everolimus (RAD001; glossary box; Weigelt et al., 2011). Whereas PIK3CA mutations and HER2 amplification have been identified in the majority of preclinical breast cancer studies as determinant of sensitivity to PI3K pathway inhibition downstream of RTKs, the correlation between PTEN deficiency and response is less clear. In some studies, results were inconclusive as 
Table 2 | Genomic determinants of response to PI3K pathway inhibitors identified in preclinical cancer models.

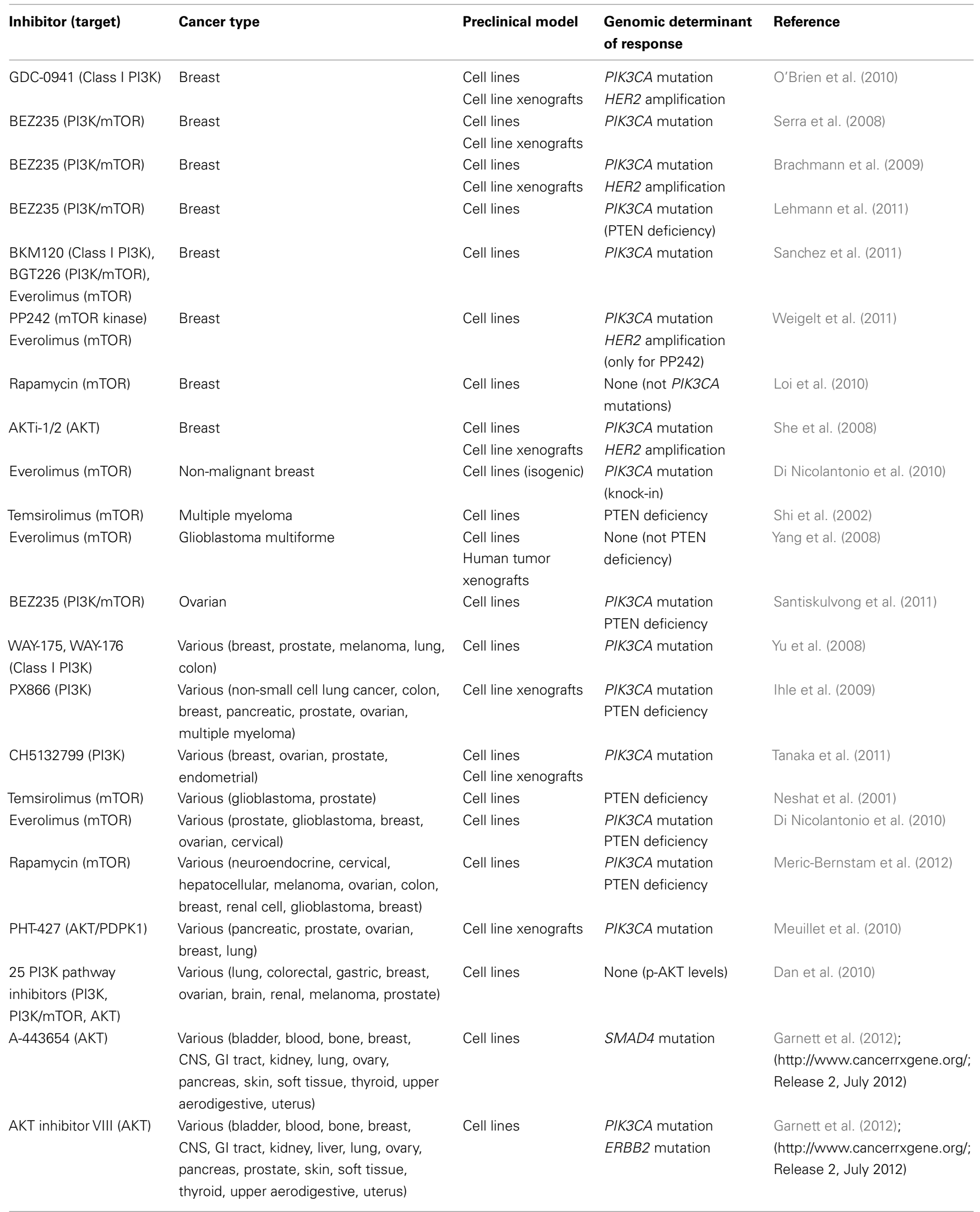


Table 2 | Continued

\begin{tabular}{|c|c|c|c|c|}
\hline Inhibitor (target) & Cancer type & Preclinical model & $\begin{array}{l}\text { Genomic determinant } \\
\text { of response }\end{array}$ & Reference \\
\hline MK-2206 (AKT) & $\begin{array}{l}\text { Various (bladder, blood, bone, breast, } \\
\text { CNS, GI tract, kidney, liver, lung, ovary, } \\
\text { pancreas, prostate, skin, soft tissue, } \\
\text { thyroid, upper aerodigestive, uterus) }\end{array}$ & Cell lines & PTEN mutation & $\begin{array}{l}\text { Garnett et al. (2012); } \\
\text { (http://www.cancerrxgene.org/; } \\
\text { Release 2, July 2012) }\end{array}$ \\
\hline AZD6482 (p110ß) & $\begin{array}{l}\text { Various (bladder, blood, bone, breast, } \\
\text { CNS, GI tract, kidney, liver, lung, ovary, } \\
\text { pancreas, prostate, skin, soft tissue, } \\
\text { thyroid, upper aerodigestive, uterus) }\end{array}$ & Cell lines & $\begin{array}{l}\text { PTEN mutation } \\
\text { PIK3CA mutation }\end{array}$ & $\begin{array}{l}\text { Garnett et al. (2012); } \\
\text { (http://www.cancerrxgene.org/; } \\
\text { Release 2, July 2012) }\end{array}$ \\
\hline BEZ235 (PI3K/mTOR) & $\begin{array}{l}\text { Various (bladder, blood, bone, breast, } \\
\text { CNS, GI tract, kidney, liver, lung, ovary, } \\
\text { pancreas, prostate, skin, soft tissue, } \\
\text { thyroid, upper aerodigestive, uterus) }\end{array}$ & Cell lines & $\begin{array}{l}\text { CDKN2A mutation } \\
\text { NRAS mutation }\end{array}$ & $\begin{array}{l}\text { Garnett et al. (2012); } \\
\text { (http://www.cancerrxgene.org/; } \\
\text { Release 2, July 2012) }\end{array}$ \\
\hline Temsirolimus (mTOR) & $\begin{array}{l}\text { Various (bladder, blood, bone, breast, } \\
\text { CNS, GI tract, kidney, liver, lung, ovary, } \\
\text { pancreas, prostate, skin, soft tissue, } \\
\text { thyroid, upper aerodigestive, uterus) }\end{array}$ & Cell lines & PTEN mutation & $\begin{array}{l}\text { Garnett et al. (2012); } \\
\text { (http://www.cancerrxgene.org/; } \\
\text { Release 2, July 2012) }\end{array}$ \\
\hline $\begin{array}{l}\text { GDC-0941 (Class I } \\
\text { PI3K), AZD8055 (mTOR } \\
\text { kinase), Rapamycin } \\
\text { (mTOR), JW-7-52-1 } \\
\text { (mTOR) }\end{array}$ & $\begin{array}{l}\text { Various (bladder, bone, breast, CNS, GI } \\
\text { tract, kidney, liver, lung, ovary, pancreas, } \\
\text { prostate, skin, soft tissue, thyroid, upper } \\
\text { aerodigestive, uterus) }\end{array}$ & Cell lines & $\begin{array}{l}\text { None (TET2 mutations } \\
\text { associated with } \\
\text { AZD8055 response, } \\
\text { however only } 3 / 554 \text { cell } \\
\text { lines were TET2 } \\
\text { mutant) }\end{array}$ & $\begin{array}{l}\text { Garnett et al. (2012); } \\
\text { (http://www.cancerrxgene.org/; } \\
\text { Release 2, July 2012) }\end{array}$ \\
\hline \multicolumn{5}{|c|}{ CONFIRMATORY STUDIES USING ANIMAL MODELS } \\
\hline BEZ235 (PI3K/mTOR) & Prostate and glioblastoma & Cell line xenografts & PTEN deficiency & Maira et al. (2008) \\
\hline Rapamycin (mTOR) & Breast and pancreatic & Cell line xenografts & PIK3CA mutation & Meric-Bernstam et al. (2012) \\
\hline $\begin{array}{l}\text { WYE-354 (mTOR } \\
\text { kinase) }\end{array}$ & Prostate and glioblastoma & Cell line xenografts & PTEN deficiency & Yu et al. (2009) \\
\hline BEZ235 (PI3K/mTOR) & Lung & $\begin{array}{l}\text { PIK3CA H1047R } \\
\text { mouse model }\end{array}$ & $\begin{array}{l}\text { PIK3CA H1047R } \\
\text { mutation }\end{array}$ & Engelman et al. (2008) \\
\hline $\begin{array}{l}\text { Rapamycin (mTOR), } \\
\text { API-2 (AKT) }\end{array}$ & Ovarian endometrioid adenocarcinoma & $\begin{array}{l}\text { Apc } c^{\text {flox/flox }} \\
\text { Pten } \\
\text { modlox/flox mouse }\end{array}$ & PTEN deficiency & Wu et al. (2011) \\
\hline
\end{tabular}

CNS, central nervous system; Gl, gastrointestinal.

only a subset of PTEN null breast cancer cell lines were sensitive to PI3K pathway inhibition (She et al., 2008; Lehmann et al., 2011; Sanchez et al., 2011), whilst others found PTEN deficient breast cancer cells to be preferentially resistant to treatment with PI3K (Tanaka et al., 2011), dual PI3K/mTOR (Brachmann et al., 2009), mTOR kinase, and allosteric mTOR inhibitors (Weigelt et al., 2011). These data are consistent with the notion that aberrations in the different components of the PI3K pathway are not necessarily equivalent in their biological impact and their potential to activate the signaling pathway (Stemke-Hale et al., 2008; Vasudevan et al., 2009; Dan et al., 2010). Moreover, these observations also suggest that sensitivity of PTEN deficient breast cancer cells to PI3K pathway inhibitors may be dependent on epistatic interactions between PI3K pathway genes and genes from other signaling pathways such as the MAPK pathway, as well as the release of negative feedback loops and the node targeted by pharmacologic inhibition (Efeyan and Sabatini, 2010; Zhang and Yu, 2010). Recent work in preclinical models has suggested that PTEN deficient cancers may depend on $\mathrm{p} 110 \beta$ rather than $\mathrm{p} 110 \alpha$ signaling (Jia et al., 2008; Wee et al., 2008; Edgar et al., 2010; Ni et al., 2012), and a p110 $\beta$ isoform specific inhibitor (GSK2636771) is currently being tested in a clinical trial of PTEN deficient malignancies (NCT01458067). In fact, as in different disease contexts selective targeting of specific p110 isoforms may be more beneficial and less toxic than pan-PI3K inhibition (Jia et al., 2009; Vanhaesebroeck et al., 2010; Jamieson

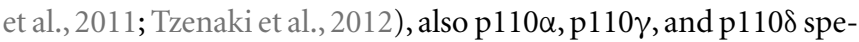
cific inhibitors are being assessed in clinical trials (Table 1). The contribution of the $\mathrm{p} 85$ isoforms (glossary box) to PI3K inhibitor response is however not yet fully understood. There is evidence to suggest that different cancer types express different levels of p110 and p85 isoforms (Cortes et al., 2012; Tzenaki et al., 2012), which may lead to tumor type-specific combinations of catalytic and regulatory PI3K subunits. It remains to be determined whether certain PI3K inhibitors show preferential activity against specific 
p110/p85 isoform combinations and whether distinct mutations in the regulatory subunits $P I K 3 R 1$ or $P I K 3 R 2$ have an impact on PI3K inhibitor response.

The general effect of PIK3CA gain-of-function mutations in the sensitization to PI3K pathway inhibitors has been confirmed in a mouse model with inducible expression of human oncogenic p110 $\alpha$ (i.e., p110 $\alpha$ H1047R), where treatment of the $\mathrm{p} 110 \alpha$ $\mathrm{H} 1047 \mathrm{R}$ driven lung adenocarcinomas with the dual PI3K/mTOR inhibitor BEZ235 led to marked tumor regression (Engelman et al., 2008). In xenografts derived from the breast cancer cell line MCF7 and the pancreatic carcinoid cell line BON, both harboring an activating PIK3CA mutation, treatment with the allosteric mTOR inhibitor Rapamycin (Sirolimus) was associated with a significant decrease in tumor volume (Meric-Bernstam et al., 2012). Moreover, using PIK3CA wild-type human breast immortalized epithelial cells (hTERT-HME1) or non-malignant MCF10A breast cells, knock-in of the E454K or H1047R PIK3CA mutant alleles sensitized non-transformed human breast cells to the rapalog Everolimus (Di Nicolantonio et al., 2010).

Also when focusing on an array of tumor types rather than on a single disease entity, PIK3CA mutant cell lines, or cell line derived xenografts were found to be selectively sensitive to PI3K pathway inhibition (Table 2). For example, analysis of xenografts derived from pancreatic, prostate, ovarian, NSCLC, and ovarian cancer cells revealed that those harboring PIK3CA mutations were among the most sensitive to the AKT inhibitor PHT-427 (Meuillet et al., 2010). This observation has been validated in a large panel of breast, ovarian, prostate, and endometrial cancer cells, given that those with PIK3CA mutations were found to be significantly more sensitive to the PI3K inhibitor $\mathrm{CH} 5132799$ in vitro than those without (Tanaka et al., 2011). Other studies assessing mixed tumor type cell line panels, however, have identified both activating PIK3CA mutations and PTEN loss of function as determinant of PI3K pathway inhibitor response. This was observed in a panel of breast, melanoma, lung, colon, prostate cancer cells treated in vitro with the PI3K inhibitors WAY-175 and WAY-176 (Yu et al., 2008), in a panel of human lung, colon, breast, pancreatic, ovarian, and multiple myeloma cell line derived xenografts treated with the PI3K inhibitor PX866 (Ihle et al., 2009), and in cell line panels of various tumor types treated in vitro with the allosteric mTOR inhibitors Everolimus (Di Nicolantonio et al., 2010) or Rapamycin (Meric-Bernstam et al., 2012). In one study, the evaluation of the in vitro efficacy of $25 \mathrm{PI} 3 \mathrm{~K}$ pathway inhibitors in a panel of 39 human cancer cell lines did not identify any genetic determinant of sensitivity (Dan et al., 2010).

It is interesting to note that whilst loss of PTEN function has been shown to be a strong activator of the PI3K pathway as determined by levels of AKT phosphorylation (Stemke-Hale et al., 2008), only a few studies identified PTEN mutations/PTEN deficiency as a single genomic determinant of response to PI3K pathway inhibitors. Murine PTEN deficient ovarian endometrioid adenocarcinomas arising in Apclox/flox $;$ Pten $^{\text {flox/flox }}$ mice have been shown to be sensitive to Rapamycin and the AKT inhibitor API-2 (Wu et al., 2011). Also in a panel of multiple myeloma (Shi et al., 2002), glioblastoma, and prostate cancer cell lines (Neshat et al., 2001), PTEN deficiency was reported to be associated with enhanced sensitivity to the allosteric mTOR inhibitor
Temsirolimus (CCI-779). Consistent with this result, the PTEN null glioblastoma cell line U-87MG and the prostate cancer cell line PC3 were found to be sensitive to Rapamycin in vitro (Di Nicolantonio et al., 2010), and when grown as xenografts to the dual PI3K/mTOR inhibitor BEZ235 (Maira et al., 2008) and the ATP-competitive mTOR inhibitor WYE-354 (Yu et al., 2009). At variance with these findings, PTEN loss of function was shown to be a poor predictor of Everolimus response in a panel of 17 glioblastoma multiforme cell lines, and in human glioblastoma xenograft models (Yang et al., 2008).

The data discussed above on the genomic determinants of PI3K pathway inhibitor response identified in vitro are based on the analysis of up to 60 cancer cell lines, which were selected based on different criteria by independent investigators. Recently, two large-scale studies subjected hundreds of cancer cell lines derived from tumors stemming from different anatomical sites and tissue types to transcriptomic profiling, copy number profiling, and massively parallel sequencing. Owing to their unprecedented scale and approach employed, these studies unraveled several associations between genetic aberrations and response to specific targeted therapies (Barretina et al., 2012; Garnett et al., 2012). Garnett et al. (2012) tested up to 714 cell lines for their response to 138 anticancer agents including ten PI3K pathway inhibitors downstream of RTKs (http://www.cancerrxgene.org/; Release 2, July 2012), and observed that, in line with previous findings, cancer cells harboring mutations in PIK3CA and PTEN were sensitive to treatment with the AKT inhibitor VIII and MK-2206, respectively. Of note, also ERBB2 mutations were associated with AKT inhibitor VIII response. Sensitivity to the AKT inhibitor A-443654 and the dual $\mathrm{PI} 3 \mathrm{~K} / \mathrm{mTOR}$ inhibitor BEZ235, however, was not determined by PI3K pathway aberrations but by the presence of SMAD4 and CDKN2A mutations, respectively (Table 2). In Garnett et al. (2012) mutations in PTEN were associated with response to the mTOR inhibitor Temsirolimus, and not only PTEN but also PIK3CA mutations predicted response to the $\mathrm{PI} 3 \mathrm{~K}$ isoform specific $\mathrm{p} 110 \beta$ inhibitor AZD6482 (http://www.cancerrxgene.org/; Release 2). On the other hand, contrary to previous reports, no mutations predictive of response to the PI3K inhibitor GDC-0941, the mTOR kinase inhibitor AZD8055, and the mTOR inhibitors Rapamycin and JW7-52-1 were identified (http://www.cancerrxgene.org/; Release 2; Garnett et al., 2012; Table 2).

Mutation analysis has already become part of the diagnostic armamentarium for lung and colon cancers (Allegra et al., 2009; Keedy et al., 2011), and is also likely to be implemented in the management of other tumor types. In fact, the potential determinants of PI3K pathway inhibitor response identified in preclinical studies may provide a rationale for the guidance of predictive biomarkers to be assessed in early clinical trials. It should be noted here that in addition to genomic response predictors also non-genetic predictors of PI3K inhibitor response have been put forward, yet none of them has been fully validated. In breast cancer, a gene expression signature predictive of in vitro sensitivity to the PI3K inhibitor GDC-0941 (O'Brien et al., 2010), and a PIK3CA mutation associated gene signature (PIK3CA-GS) derived from exon 20 PIK3CA mutations able to predict PIK3CA mutation status in primary breast cancers and predictive of Rapamycin response in vitro have recently been described (Loi et al., 2010). In addition, several 
groups found increased phosphorylated (p)-AKT baseline levels as a read-out for PI3K pathway activation to be associated with its therapeutic intervention (Noh et al., 2004; Yu et al., 2008; Dan et al., 2010; Meric-Bernstam et al., 2012). Despite the potential utility of these approaches, it should be mentioned that gene expression signatures and immunohistochemical assessment of phosphorylated proteins have proven challenging to implement in routine clinical practice (Pinhel et al., 2010; Weigelt et al., 2012).

Although predictive markers of sensitivity to PI3K pathway inhibitors, such as PIK3CA mutations, are of importance for treatment tailoring, markers predictive of resistance may be useful. In fact, tumors harboring a given therapeutic target not uncommonly display primary (i.e., de novo) resistance or develop resistance over time (van der Heijden and Bernards, 2010; Turner and Reis-Filho, 2012). In several studies discussed here assessing determinants of single agent PI3K pathway inhibitor response, KRAS mutations were found to be associated with resistance to these targeted agents (Engelman et al., 2008; Brachmann et al., 2009; Ihle et al., 2009; Dan et al., 2010; Meuillet et al., 2010; Garnett et al., 2012), as were mutations in APC, BRAF, or MYCN (http://www.cancerrxgene.org/; Garnett et al., 2012).

Finally, in addition to genetic alterations of components of the PI3K pathway germline polymorphisms may affect response of patients treated with targeted therapies. Ng et al. (2012) have recently identified a common intronic deletion polymorphism of the BIM gene that leads to the generation of an alternative spliced $\mathrm{BIM}$ isoform lacking the $\mathrm{BH} 3$ domain, which is required for tyrosine kinase inhibitor induced apoptosis. This polymorphism was shown to confer intrinsic resistance to RTK inhibitors in chronic myeloid leukemia and EGFR mutated NSCLC cell lines (Ng et al., 2012). It is plausible that this and other germline polymorphisms may results in resistance to agents targeting the PI3K pathway.

Taken together, preclinical studies focusing on breast cancer only have repeatedly identified PIK3CA mutations and HER2 amplifications as predictors of sensitivity to PI3K pathway inhibitors. In other tumor types, however, the genotype-drug response associations are less defined and PIK3CA mutations, PTEN loss of function or both, or CDKN2A mutations have been reported as determinants of response. Furthermore, the in vitro and animal model studies revealed that in cancer cells other than breast cancer, where MAPK pathway mutations are rare (COS$\mathrm{MIC}$ ), KRAS mutations may confer resistance to single agent PI3K pathway inhibitor treatment, as do mutations in BRAF, APC and MYCN.

\section{GENOMIC DETERMINANTS OF PI3K PATHWAY INHIBITOR RESPONSE IN CLINICAL TRIALS}

Rapamycin analogs ("rapalogs"; glossary box) were the first PI3K pathway inhibitors to be tested in clinical trials for the treatment of cancer, and Everolimus and Temsirolimus have been approved by the US Food and Drug Administration (FDA) for the treatment of advanced renal cell carcinoma (ARCC), and Everolimus has also been approved for the treatment of progressive neuroendocrine tumors of pancreatic origin and non-malignant kidney and brain tumors (Table $\mathbf{1}$ ).

The determinants of mTOR inhibition in renal cell carcinomas may differ from those of other solid malignancies. In fact, clear cell renal cell carcinomas rarely harbor mutations in PI3K pathway components (COSMIC), however commonly show loss of function of the tumor suppressor genes PTEN (Brenner et al., 2002; Velickovic et al., 2002) or von Hippel Lindau (VHL), a critical regulator of the hypoxic response (Kim and Kaelin, 2004; Linehan et al., 2010). Clear cell renal cell cancer has been suggested to be a cell metabolism, angiogenesis-dependent and hypoxia-driven disease, and its response to mTOR inhibition thought to stem from its impact on proliferation and cell survival but also from the fact that the hypoxia-inducible-factor $1-\alpha$ (HIF1- $\alpha)$ is under translational control of the mTOR complex 1 (mTORC1; glossary box; Thomas et al., 2006; Linehan et al., 2010). Exploratory subgroup analysis of the 209 patients from the Temsirolimus single agent arm of the phase III global ARCC trial (Hudes et al., 2007) investigated PTEN and HIF1- $\alpha$ protein expression levels by immunohistochemistry (IHC) on formalin fixed paraffin embedded nephrectomy or core biopsy derived tissues. Importantly, baseline PTEN or HIF1- $\alpha$ levels were shown not to be associated with single agent Temsirolimus response (Figlin et al., 2009; Table 3). Furthermore, in a retrospective subgroup analysis from a phase II clinical trial of ARCC (Atkins et al., 2004) including 20 patients (Cho et al., 2007), carbonic anhydrase IX (CA9), p-AKT, and PTEN protein expression levels using IHC or VHL mutation status were shown not to be significantly associated with single agent Temsirolimus response. There was, however, a significant positive association between higher p-rpS6 expression, a downstream effector of mTORC1 (Figure 1), and clinical Temsirolimus response (Cho et al., 2007). It should be noted that the analysis above was performed in a limited number of patients and their statistical power to reveal the associations should be taken into account.

The vast majority of completed to date trials testing PI3K pathway inhibitors in tumor types other than renal cell carcinoma also focused on rapalogs, but only few studies assessed potential genomic predictors (Table 3 ). Based on the rationale that PIK3CA mutations may predict response to PI3K pathway inhibitors, breast, cervical, endometrial, and ovarian cancers were sequenced for the presence of activating PIK3CA mutations and treated with different allosteric $\mathrm{mTOR}$ inhibitors (i.e., rapalogs) or the PI3K inhibitor PX866 either as single agent or combination in a prospective phase I clinical trial. A partial response was observed in $30 \%$ of the 23 patients with tumors harboring a PIK3CA mutation in contrast to $10 \%$ of 70 patients whose tumors were PIK3CA wildtype (Janku et al., 2012), consistent with the preclinical observations. Interestingly, whilst in preclinical models mutations in KRAS have been found to confer resistance to PI3K pathway inhibition, as discussed above, in this trial 2/7 ovarian cancer patients with coexisting PIK3CA and KRAS or BRAF mutations responded to the anti-PI3K pathway treatment (Janku et al., 2012). This finding may be tumor type-specific, given that the same group had previously described that colorectal cancers harboring simultaneous PIK3CA and KRAS mutations were resistant to PI3K pathway inhibitor treatment (Janku et al., 2011). A similar, but not statistically significant, trend was observed in a retrospective subgroup analysis of 43 patients with different tumor types but most frequently colorectal cancer from phase I/II clinical study of single agent Everolimus (Tabernero et al., 2008; Di Nicolantonio et al., 2010). Patients whose tumors harbored PIK3CA mutations or PTEN loss 


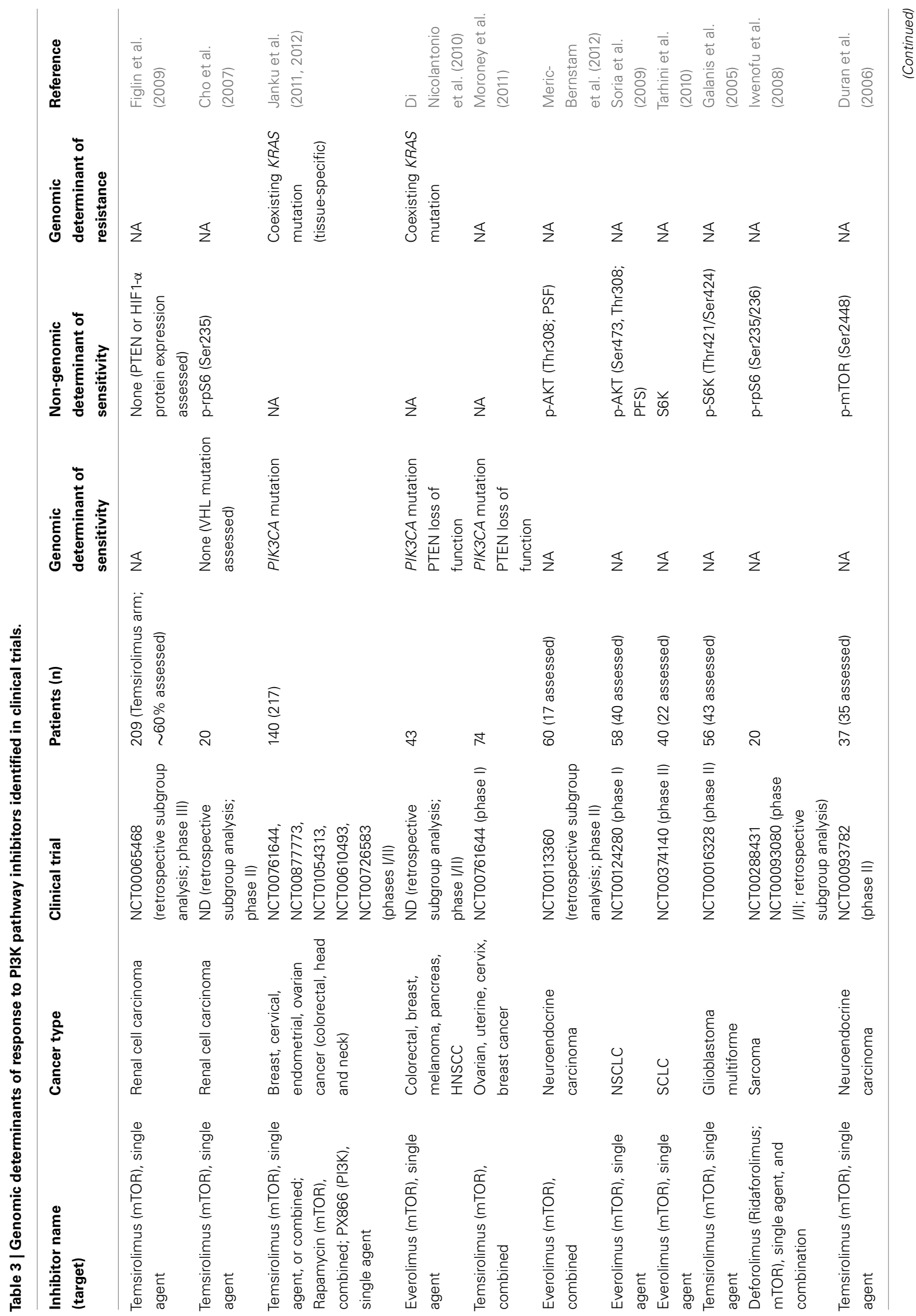




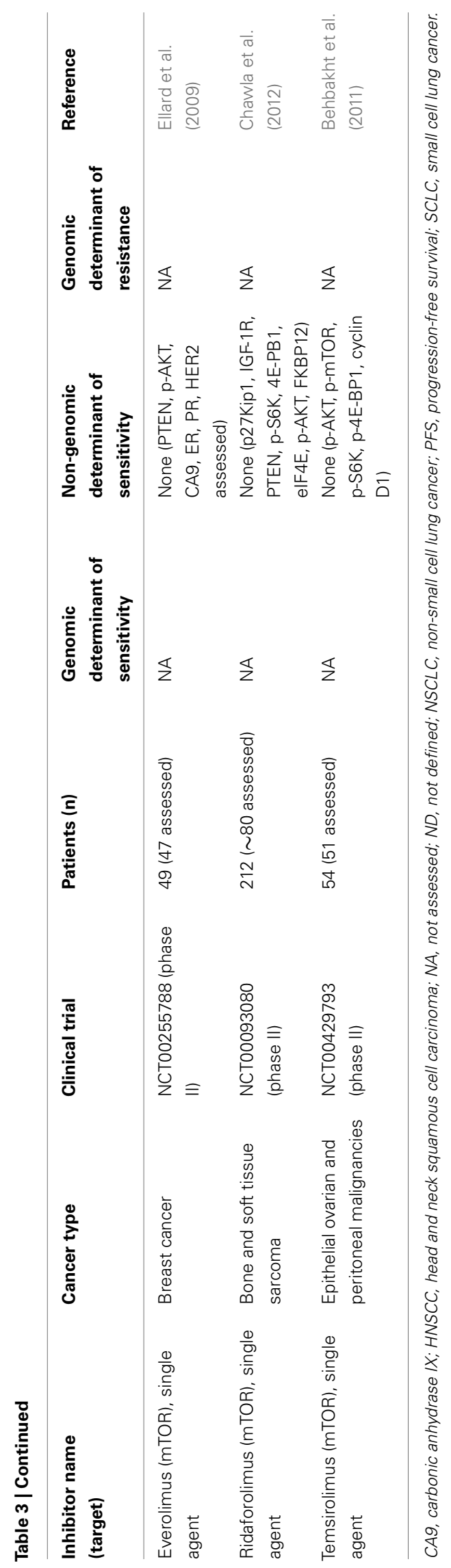

of function were more likely to benefit from Everolimus, except in presence of coexistent KRAS/BRAF mutations (Di Nicolantonio et al., 2010). A high percentage of responders with PI3K pathway aberrations as determined by PIK3CA mutations or PTEN loss of function was also reported in a phase I trial of liposomal Doxorubicin, Bevacizumab, and Temsirolimus (Moroney et al., 2011). Taken together, these results suggest PI3KCA gainof-function mutations may predict sensitivity to PI3K pathway inhibitors, whereas KRAS and BRAF mutations may lead to resistance in some tumor types such as colorectal cancer. Importantly, however, the data available demonstrate that PIK3CA activating mutations are neither required nor sufficient for a tumor to be sensitive to PI3K pathway inhibitors, and that a substantial proportion of cases with PIK3CA activating mutations may be de novo resistant to these agents.

Not only genomic predictors but also PI3K pathway activation state as determined by expression levels of markers upstream of mTORC1, such as p-AKT, or downstream of mTORC1, such as p-S6K (Figure 1), have been shown to correlate with sensitivity to allosteric mTOR inhibitors in breast cancer cell lines in vitro (Noh et al., 2004; Meric-Bernstam et al., 2012). In fact, several clinical trials testing rapalogs evaluated PI3K signaling biomarkers on baseline tumor tissue by IHC rather than performing sequencing analysis. In a phase II study, high p-AKT levels on baseline and on-treatment fine needle aspirations of tumors from patients with neuroendocrine carcinoma $(n=17)$ assessed by reverse phase protein arrays correlated with longer progression-free survival (PFS; Meric-Bernstam et al., 2012). Moreover, in NSCLC patients treated with Everolimus $(n=40)$, p-AKT levels at baseline determined by IHC were reported to be independent predictors of PFS (Soria et al., 2009; Table 3). It should be noted, however, that the authors emphasized that tissue fixation had large effects on immunoreactivity when assessing phosphorylated proteins, which may compound the implementation of this IHC predictive test in clinical practice.

In a phase II trial, p-S6K levels assessed by IHC in baseline glioblastoma multiforme samples were associated with single agent Temsirolimus response $(n=44$; Galanis et al., 2005). Also in a small retrospective subgroup analysis of two phase I/II clinical trials p-rpS6, downstream of p-S6K, was correlated with early response of sarcomas to the rapalog Deforolimus (i.e., Ridaforolimus) alone or in combination with doxorubicin $(n=20$; Iwenofu et al., 2008). Not only expression levels of activated (i.e., phosphorylated) S6K/rpS6 have been found to correlate with response to allosteric mTOR inhibitors, but in phase II study, total S6K expression in baseline SCLC tumor tissue defined by IHC was reported as a potential predictive biomarker for the therapeutic benefit of Everolimus ( $n=22$; Tarhini et al., 2010). In addition, higher baseline levels of p-mTOR itself assessed by IHC predicted for a better response to Temsirolimus in patients with neuroendocrine carcinoma in a phase II study $(n=35$; Duran et al., 2006).

Other, similarly powered phase II trials however did not identify any correlates between potential biomarkers assessed in archival tumor material using IHC and treatment response (Table 3). In metastatic breast cancers, no association between p-AKT, PTEN, CA9, ER, progesterone receptor or HER2 expression, and response 
to Everolimus was found (Ellard et al., 2009). In bone and soft tissue sarcomas, an extended subgroup analysis $(n \approx 80$; Chawla et al., 2012) did not confirm the previously published analysis on 20 patients, which identified p-rpS6 levels as Ridaforolimus response predictors (Iwenofu et al., 2008). In fact, neither the potential biomarkers upstream of mTORC1, including PTEN, p-AKT, FKBP21, or IGF-1R, nor downstream of mTORC1, pS6K, 4E-BP1, eIF4E, or p27kip1, were predictive of clinical benefit response to Ridaforolimus (Chawla et al., 2012). Furthermore, p-AKT, p-mTOR, p-4E-BP1, and cyclin D1 expression levels in epithelial ovarian and peritoneal tumors were shown not to be associated with partial/complete tumor responses to Temsirolimus, however cyclin D1 expression seemed to correlate with PFS $\geq 6$ months (Behbakht et al., 2011).

The completed phase I/II clinical trials to date are to some extent consistent with the preclinical observations in that tumors harboring PIK3CA mutations may be more likely to respond to PI3K pathway inhibitors. It is important to note, however, that not all patients with tumors harboring PIK3CA mutations are sensitive to PI3K pathway inhibitor treatment, and, on the other hand, that also subsets of patients with wild-type PIK3CA/PTEN cancers are responsive. The results from studies analyzing the activation state of PI3K pathway components by IHC are variable and no consistent determinant of response has been identified to date.

\section{DEVELOPMENT OF MOLECULAR TOOLS FOR THE STRATIFICATION OF CANCER PATIENTS}

For the development of molecular markers for patient stratification in clinical trials testing the efficacy of PI3K pathway inhibitors, it is crucial to take into account the observations that in some tumor types, either PIK3CA activating mutations or PTEN loss of function are predictors of sensitivity, whereas in other tumor types, both predict sensitivity to these agents (Table 2). These data imply that the mutational repertoire and the epistatic interactions between different components of the PI3K pathway may be distinct in different tumor types, that genetic lesions in different components of the pathway may not have the same functional effects in different tumor types, and that a genetic determinant identified in one cancer type may not necessarily be applicable to another. This is perhaps best exemplified by $B R A F^{\mathrm{V} 600 \mathrm{E}}$ mutations, which are predictive of response to Vemurafenib in melanoma, however colorectal cancer patients harboring oncogenic $B R A F^{\mathrm{V} 600 \mathrm{E}}$ mutations derive limited if any benefit from this drug due to increased EGFR expression (Prahallad et al., 2012). Likewise, the clinical trials discussed above provide evidence to suggest that ovarian cancers with coexisting PIK3CA and MAPK pathway mutations may be sensitive to PI3K pathway inhibition, whereas colorectal cancers harboring the same repertoire of mutations affecting these genes may be resistant (Di Nicolantonio et al., 2010; Janku et al., 2011, 2012).

Results from preclinical studies performed have further suggested that cancer cells harboring PIK3CA mutations might be among the most sensitive to single agent PI3K pathway inhibitors. These data were in part confirmed in the three clinical trials assessing tumor PIK3CA mutational status (Di Nicolantonio et al., 2010; Janku et al., 2011, 2012; Moroney et al., 2011). The predictive value of the PTEN status is however less clear, as in some clinical trials an association between PTEN deficiency and PI3K pathway inhibitor response was found (Di Nicolantonio et al., 2010; Moroney et al., 2011) but not in others (Ellard et al., 2009; Figlin et al., 2009; Chawla et al., 2012). A similar picture is seen when expression levels of phosphorylated proteins of the PI3K pathway are used as a read-out of its activation state and determinant of response (Table 3). IHC of phosphorylated proteins has proven challenging (Soria et al., 2009; Pinhel et al., 2010) and also PTEN staining is not routinely performed. Recent reports focused on the reproducibility of PTEN staining protocols and scoring (Sakr et al., 2010; Garg et al., 2012), however guidelines for accurate PTEN testing and its utility as predictive marker have yet to be established.

Early clinical trials often analyze archival tissue of the primary tumor for the presence of specific mutations and the response of the metastatic lesions are correlated with the mutational status. Recent analyses of paired primary tumors and metastases have revealed that there is a high level of discordance in PTEN expression level and PIK3CA mutation status, which may influence patient selection and response to PI3K targeted therapies (Dupont Jensen et al., 2011; Gonzalez-Angulo et al., 2011).

Despite the interest in the development of biomarkers for patient selection in clinical trials testing PI3K pathway inhibitors, none of the biomarkers tested so far is supported by level I evidence. Importantly, however, one of the most exciting results of allosteric mTOR inhibitors in the context of a clinical study was the BOLERO-2 trial, where patients with ER-positive advanced breast cancers resistant to aromatase inhibitors were randomized to receive Exemestane (a non-steroidal aromatase inhibitor) plus Everolimus or Exemestane plus Placebo (Baselga et al., 2012). The rationale for this stemmed from preclinical observations that resistance to endocrine therapy in breast cancer is associated with activation of the PI3K pathway (Miller et al., 2011). Despite the lack of a patient stratification biomarker, this trial demonstrated that addition of Everolimus to Exemestane increased the median PFS from 4.1 to 10.6 months (Baselga et al., 2012). Although a substantial proportion of patients included in this trial may harbor PIK3CA activating mutations, given that they are more likely to occur in ER-positive postmenopausal patients (Kalinsky et al., 2009), other mechanisms resulting in PI3K pathway activation are likely to play a role in resistance to endocrine therapy. The material from this trial will constitute a unique resource to determine the genomic and epigenomic determinants of sensitivity to concurrent mTOR inhibition and endocrine treatment in breast cancer.

\section{FUTURE PERSPECTIVES AND CHALLENGES}

Despite the critical role of the PI3K pathway in cancer, the introduction of single-agent PI3K pathway inhibitors into the clinic may be challenging. In fact, of all PI3K pathway inhibitors discussed here, one of the most exciting targeted agents is the p110 $\delta$ inhibitor CAL-101, which has shown remarkable clinical activity in certain hematological diseases including chronic lymphocytic leukemia. Inhibition of p1 $10 \delta$ is though to target both the malignant $B$ cells and the tumor microenvironment of chronic lymphoid leukemia (Fruman and Rommel, 2011). The clinical trials performed thus far using allosteric mTOR inhibitors as single agents have seen some stable diseases and partial responses, however by no means are these responses as dramatic as for example for Vemurafenib in BRAF mutant melanoma (Flaherty et al., 2010). 
Based in the preclinical data, kinase inhibitors seem to target the PI3K pathway more robustly and, in contrast to allosteric mTOR inhibitors, also promote apoptotic effects in vitro and in vivo (Brachmann et al., 2009; O’Brien et al., 2010; Weigelt et al., 2011). Several feedback loops upon PI3K/AKT/mTOR inhibition have been described, which amongst others lead to activation of the MAPK signaling pathway or re-activation of the PI3K pathway (reviewed in Carracedo and Pandolfi, 2008; Efeyan and Sabatini, 2010; Chandarlapaty, 2012; Laplante and Sabatini, 2012). These feedbacks may play a role in the modest responses observed thus far using single agent rapalogs, and for the optimal activity of PI3K pathway inhibitors, co-administration with other agents may be required.

Numerous clinical trials are currently testing the safety and efficacy of combination PI3K pathway and MEK inhibitors in advanced solid tumors to target both the driver and potential "escape" pathways. As discussed above, such combinatorial approach has been successfully performed in breast cancer, where the combination of an aromatase inhibitor with Everolimus led to substantial improvement of PFS (Baselga et al., 2012). For the identification of optimal combinations of PI3K pathway inhibitors with other agents, Drosophila models may provide an effective tool as these have been successfully employed for the identification of agents with optimized pharmacological profiles (Das and Cagan, 2010; Dar et al., 2012). For combinatorial treatments it will be crucial to understand the activation of negative feedback loops in the PI3K pathway and the cross-talk with other pathway upon inhibition of its different components, and whether the feedback activation is dependent on specific epistatic interactions and distinct in tumors from different anatomical sites.

Drug sensitivity and resistance are likely to constitute convergent phenotypes, meaning that they may be driven by distinct genetic aberrations in the same tumor type (Gerlinger and Swanton, 2010; Turner and Reis-Filho, 2012; Weigelt et al., 2012; Yap et al., 2012). It has become apparent from in vitro studies that there are significant correlations between specific mutations and treatment response, however the negative predictive value of these mutations is often poor and not all sensitive cancers are identified by single mutations/single gene panels. For example, O'Brien et al. (2010) showed that in their cell line panel tested, PIK3CA mutations and HER2 amplification showed excellent specificity (100 and $95 \%$, respectively) and a high positive predictive value, but relatively low sensitivity $(\sim 30 \%)$ and a poor negative predictive value as single markers in predicting drug responsiveness in the cell line panel analyzed. Additional biomarkers will therefore be required to identify all patients likely to respond to PI3K pathway inhibitors. To date, the majority of studies have focused on the analysis of PIK3CA mutations or PTEN deficiency as potential determinants of PI3K pathway inhibitor response. However, also activating mutations in other components of the pathway, such as PIK3R1 (Jaiswal et al., 2009; Urick et al., 2011) or mTOR (Sato et al., 2010; Hardt et al., 2011), or loss of function of TSC1/2 (COSMIC; El-Hashemite et al., 2003; Sjodahl et al., 2011) or INPP4B (Gewinner et al., 2009; Fedele et al., 2010) may play a role in PI3K pathway inhibitor response. Furthermore, and as mentioned above, the remarkable single agent activity of the PI3K isoform specific p $110 \delta$ inhibitor CAL-101 in chronic lymphocytic leukemia, a disease in which PI3K pathway aberrations are relatively rare, emphasizes that some targeted agents may be effective in vivo due to targeting of tumor microenvironment interactions (Fruman and Rommel, 2011), which are unlikely to be uncovered using conventional in vitro cell culture models or by the genomic characterization of tumor cells only.

With the advent of massively parallel sequencing technologies, several studies have documented intra-tumor genetic heterogeneity in solid cancers (reviewed in Turner and Reis-Filho, 2012; Yap et al., 2012), and revealed that certain mutations, including PIK3CA or PTEN mutations, may be only prevalent in a subset of tumor cells in a given cancer (Gerlinger et al., 2012; Shah et al., 2012). This has not only consequences for cancer drug resistance and the clinical utility of single agent targeted therapy, but also questions whether potential biomarkers assessed in a single biopsy will be representative of the entire tumor.

Given the crucial role of the PI3K pathway in cancer, inhibitors of its components are expected to be effective in subsets of many different cancer types. Preclinical models have proven useful in the identification of potential predictive biomarkers, however tissue collection and assessment of biomarkers even in early clinical trials are crucial, as is the development of robust and accurate companion diagnostics. With the number of ongoing clinical trials currently testing a wide gamut of PI3K pathway inhibitors, our community should expect a wealth of data, which will help improve therapeutic strategies for cancer patients.

\section{GLOSSARY}

\section{PHOSPHOINOSITIDE 3-KINASE CLASSES}

According to their structures and substrate specificities, PI3Ks are divided into three classes, and class I PI3Ks are directly activated by cell surface receptors (Liu et al., 2009). Class IA PI3Ks are heterodimeric lipid kinases composed of a p110 catalytic subunit (isoforms $\mathrm{p} 110 \alpha, \mathrm{p} 110 \beta$, and $\mathrm{p} 110 \delta$, encoded by PIK3CA, $P I K 3 C B$, and PIK3CD, respectively), and a regulatory subunit (p85 $\alpha$ and its splice variants p55 $\alpha$ and $\mathrm{p} 50 \alpha$ ), p85 $\beta$, and p55 $\gamma$, encoded by PIK3R1, PIK3R2, and PIK3R3, respectively); the class IB PI3K is composed of the p110 $\gamma$ catalytic subunit, encoded by PIK3CG, and the regulatory subunit p101, p84/p87 (Liu et al., 2009; Vanhaesebroeck et al., 2010).

\section{RAPAMYCIN AND RAPAMYCIN ANALOGS ("RAPALOGS")}

Mechanistic target of rapamycin is a serine/threonine kinase that interacts with several proteins to form two distinct signaling complexes called mTORC1 and mTORC2 (Laplante and Sabatini, 2012). Rapamycin and rapamycin analogs ("rapalogs") bind the FK506-binding protein (FKBP12) and together target preferentially the mTORC1 by an allosteric mechanism, however prolonged treatment may also inhibit mTORC2 and disrupt its main substrate AKT, possibly in a tissue-specific manner (Sarbassov et al., 2006; Lamming et al., 2012).

\section{ACKNOWLEDGMENTS}

We apologize to those authors whose work we could not cite directly due to space constraints. We would like to thank J. S. Reis-Filho (The Breakthrough Breast Cancer Centre, London) for advice and critical reading of the manuscript. Britta Weigelt is funded by a Cancer Research UK postdoctoral fellowship. 


\section{REFERENCES}

Allegra, C. J., Jessup, J. M., Somerfield, M. R., Hamilton, S. R., Hammond, E. H., Hayes, D. F., Mcallister, P. K., Morton, R. F., and Schilsky, R. L. (2009). American Society of Clinical Oncology provisional clinical opinion: testing for KRAS gene mutations in patients with metastatic colorectal carcinoma to predict response to anti-epidermal growth factor receptor monoclonal antibody therapy. J. Clin. Oncol. 27, 2091-2096.

Antonescu, C. R. (2011). The GIST paradigm: lessons for other kinasedriven cancers. J. Pathol. 223, 251-261.

Atkins, M. B., Hidalgo, M., Stadler, W. M., Logan, T. F., Dutcher, J. P., Hudes, G. R., Park, Y., Liou, S. H., Marshall, B., Boni, J. P., Dukart, G., and Sherman, M. L. (2004). Randomized phase II study of multiple dose levels of CCI-779, a novel mammalian target of rapamycin kinase inhibitor, in patients with advanced refractory renal cell carcinoma. J. Clin. Oncol. 22, 909-918.

Bader, A. G., Kang, S., Zhao, L., and Vogt, P. K. (2005). Oncogenic PI3K deregulates transcription and translation. Nat. Rev. Cancer 5, 921-929.

Barretina, J., Caponigro, G., Stransky, N., Venkatesan, K., Margolin, A. A., Kim, S., Wilson, C. J., Lehar, J., Kryukov, G. V., Sonkin, D., Reddy, A., Liu, M., Murray, L., Berger, M. F., Monahan, J. E., Morais, P., Meltzer, J., Korejwa, A., Jane-Valbuena, J., Mapa, F. A., Thibault, J., Bric-Furlong, E., Raman, P., Shipway, A., Engels, I. H., Cheng, J., Yu, G. K., Yu, J., Aspesi, P. Jr., De Silva, M., Jagtap, K., Jones, M. D., Wang, L., Hatton, C., Palescandolo, E., Gupta, S., Mahan, S., Sougnez, C., Onofrio, R. C., Liefeld, T., Macconaill, L., Winckler, W., Reich, M., Li, N., Mesirov, J. P., Gabriel, S. B., Getz, G., Ardlie, K., Chan, V., Myer, V. E., Weber, B. L., Porter, J., Warmuth, M., Finan, P., Harris, J. L., Meyerson, M., Golub, T. R., Morrissey, M. P., Sellers, W. R., Schlegel, R., and Garraway, L. A. (2012). The Cancer Cell Line Encyclopedia enables predictive modelling of anticancer drug sensitivity. Nature 483, 603-607.

Baselga, J., Campone, M., Piccart, M., Burris, H. A. III, Rugo, H. S., Sahmoud, T., Noguchi, S., Gnant, M., Pritchard, K. I., Lebrun, F., Beck, J. T., Ito, Y., Yardley, D., Deleu, I., Perez, A., Bachelot, T., Vittori, L., Xu, Z., Mukhopadhyay, P., Lebwohl, D., and Hortobagyi, G. N. (2012). Everolimus in postmenopausal hormonereceptor-positive advanced breast cancer. N. Engl. J. Med. 366, 520-529.

Behbakht, K., Sill, M. W., Darcy, K. M., Rubin, S. C., Mannel, R. S., Waggoner, S., Schilder, R. J., Cai, K. Q., Godwin, A. K., and Alpaugh, R. K. (2011). Phase II trial of the mTOR inhibitor, temsirolimus and evaluation of circulating tumor cells and tumor biomarkers in persistent and recurrent epithelial ovarian and primary peritoneal malignancies: a Gynecologic Oncology Group study. Gynecol. Oncol. 123, 19-26.

Brachmann, S. M., Hofmann, I., Schnell, C., Fritsch, C., Wee, S., Lane, H., Wang, S., Garcia-Echeverria, C., and Maira, S. M. (2009). Specific apoptosis induction by the dual $\mathrm{PI} 3 \mathrm{~K} / \mathrm{m}$ Tor inhibitor NVPBEZ235 in HER2 amplified and PIK3CA mutant breast cancer cells. Proc. Natl. Acad. Sci. U.S.A. 106, 22299-22304.

Brenner, W., Farber, G., Herget, T., Lehr, H. A., Hengstler, J. G., and Thuroff, J. W. (2002). Loss of tumor suppressor protein PTEN during renal carcinogenesis. Int. J. Cancer 99, 53-57.

Carden, C. P., Sarker, D., Postel-Vinay, S., Yap, T. A., Attard, G., Banerji, U., Garrett, M. D., Thomas, G. V., Workman, P., Kaye, S. B., and De Bono, J. S. (2010). Can molecular biomarkerbased patient selection in Phase I trials accelerate anticancer drug development? Drug Discov. Today 15, 88-97.

Carracedo, A., and Pandolfi, P. P. (2008). The PTEN-PI3K pathway: of feedbacks and cross-talks. Oncogene 27, 5527-5541.

Chandarlapaty, S. (2012). Negative feedback and adaptive resistance to the targeted therapy of cancer. Cancer Discov. 2, 311-319.

Chawla, S. P., Staddon, A. P., Baker, L. H., Schuetze, S. M., Tolcher, A. W., D’Amato, G. Z., Blay, J. Y., Mita, M. M., Sankhala, K. K., Berk, L., Rivera, V. M., Clackson, T., Loewy, J. W., Haluska, F. G., and Demetri, G. D. (2012). Phase II study of the mammalian target of rapamycin inhibitor ridaforolimus in patients with advanced bone and soft tissue sarcomas. J. Clin. Oncol. 30, 78-84.

Cho, D., Signoretti, S., Dabora, S., Regan, M., Seeley, A., Mariotti, M., Youmans, A., Polivy, A., Mandato, L. Mcdermott, D., Stanbridge, E., and Atkins, M. (2007). Potential histologic and molecular predictors of response to temsirolimus in patients with advanced renal cell carcinoma. Clin. Genitourin. Cancer 5, 379-385.
Cortes, I., Sanchez-Ruiz, J., Zuluaga, S., Calvanese, V., Marques, M., Hernandez, C., Rivera, T., Kremer, L., Gonzalez-Garcia, A., and Carrera, A. C. (2012). p85beta phosphoinositide 3-kinase subunit regulates tumor progression. Proc. Natl. Acad. Sci. U.S.A. 109, 11318-11323.

Dan, S., Okamura, M., Seki, M. Yamazaki, K., Sugita, H., Okui, M., Mukai, Y., Nishimura, H., Asaka, R., Nomura, K., Ishikawa, Y., and Yamori, T. (2010). Correlating phosphatidylinositol 3-kinase inhibitor efficacy with signaling pathway status: in silico and biological evaluations. Cancer Res. 70, 4982-4994.

Dar, A. C., Das, T. K., Shokat, K. M. and Cagan, R. L. (2012). Chemical genetic discovery of targets and anti-targets for cancer polypharmacology. Nature 486, 80-84.

Das, T., and Cagan, R. (2010). Drosophila as a novel therapeutic discovery tool for thyroid cancer. Thyroid 20, 689-695.

Di Nicolantonio, F., Arena, S. Tabernero, J., Grosso, S., Molinari, F., Macarulla, T., Russo, M., Cancelliere, C., Zecchin, D., Mazzucchelli, L., Sasazuki, T., Shirasawa, S. Geuna, M., Frattini, M., Baselga, J., Gallicchio, M., Biffo, S., and Bardelli, A. (2010). Deregulation of the PI3K and KRAS signaling pathways in human cancer cells determines their response to everolimus. J. Clin. Invest. 120, 2858-2866.

Dupont Jensen, J., Laenkholm, A. V., Knoop, A., Ewertz, M., Bandaru, R., Liu, W., Hackl, W., Barrett, J. C., and Gardner, H. (2011). PIK3CA mutations may be discordant between primary and corresponding metastatic disease in breast cancer. Clin. Cancer Res. 17, 667-677.

Duran, I., Kortmansky, J., Singh, D., Hirte, H., Kocha, W., Goss, G., Le, L., Oza, A., Nicklee, T., Ho, J., Birle, D., Pond, G. R., Arboine, D., Dancey, J., Aviel-Ronen, S., Tsao, M. S., Hedley, D., and Siu, L. L. (2006). A phase II clinical and pharmacodynamic study of temsirolimus in advanced neuroendocrine carcinomas. $\mathrm{Br} . \mathrm{J}$. Cancer 95, 1148-1154.

Edgar, K. A., Wallin, J. J., Berry, M. Lee, L. B., Prior, W. W., Sampath, D., Friedman, L. S., and Belvin, M. (2010). Isoform-specific phosphoinositide 3-kinase inhibitors exert distinct effects in solid tumors. Cancer Res. 70, 1164-1172.

Efeyan, A., and Sabatini, D. M. (2010). mTOR and cancer: many loops in one pathway. Curr. Opin. Cell Biol. 22, 169-176.
El-Hashemite, N., Zhang, H., Henske, E. P., and Kwiatkowski, D. J. (2003). Mutation in TSC2 and activation of mammalian target of rapamycin signalling pathway in renal angiomyolipoma. Lancet 361, 1348-1349.

Ellard, S. L., Clemons, M., Gelmon, K. A., Norris, B., Kennecke, H., Chia, S., Pritchard, K., Eisen, A., Vandenberg, T., Taylor, M., Sauerbrei, E., Mishaeli, M., Huntsman, D., Walsh, W., Olivo, M., Mcintosh, L., and Seymour, L. (2009). Randomized phase II study comparing two schedules of everolimus in patients with recurrent/metastatic breast cancer: NCIC Clinical Trials Group IND.163. J. Clin. Oncol. 27, 4536-4541.

Engelman, J. A., Chen, L., Tan, X., Crosby, K., Guimaraes, A. R., Upadhyay, R., Maira, M., Mcnamara, K., Perera, S. A., Song, Y., Chirieac, L. R., Kaur, R., Lightbown, A., Simendinger, J., Li, T., Padera, R. F., Garcia-Echeverria, C., Weissleder, R., Mahmood, U., Cantley, L. C., and Wong, K. K. (2008). Effective use of PI3K and MEK inhibitors to treat mutant Kras G12D and PIK3CA H1047R murine lung cancers. Nat. Med. 14, 1351-1356.

Engelman, J. A., Luo, J., and Cantley, L. C. (2006). The evolution of phosphatidylinositol 3-kinases as regulators of growth and metabolism. Nat. Rev. Genet. 7, 606-619.

Fedele, C. G., Ooms, L. M., Ho, M., Vieusseux, J., O’Toole, S. A., Millar, E. K., Lopez-Knowles, E., Sriratana, A., Gurung, R., Baglietto, L., Giles, G. G., Bailey, C. G., Rasko, J. E., Shields, B. J., Price, J. T., Majerus, P. W., Sutherland, R. L., Tiganis, T., Mclean, C. A., and Mitchell, C. A. (2010). Inositol polyphosphate 4-phosphatase II regulates PI3K/Akt signaling and is lost in human basal-like breast cancers. Proc. Natl. Acad. Sci. U.S.A. 107, 22231-22236.

Figlin, R. A., De Souza, P., Mcdermott, D., Dutcher, J. P., Berkenblit, A., Thiele, A., Krygowski, M., Strahs, A., Feingold, J., Boni, J., and Hudes, G. (2009). Analysis of PTEN and HIF1alpha and correlation with efficacy in patients with advanced renal cell carcinoma treated with temsirolimus versus interferon-alpha. Cancer 115, 3651-3660.

Flaherty, K. T., Puzanov, I., Kim, K. B., Ribas, A., Mcarthur, G. A., Sosman, J. A., O’Dwyer, P. J., Lee, R. J., Grippo, J. F., Nolop, K., and Chapman, P. B. (2010). Inhibition of mutated, activated BRAF in metastatic melanoma. N. Engl. J. Med. 363, 809-819. 
Forbes, S. A., Bindal, N., Bamford, S., Cole, C., Kok, C. Y., Beare, D., Jia, M., Shepherd, R., Leung, K., Menzies, A., Teague, J. W., Campbell, P. J., Stratton, M. R., and Futreal, P. A. (2011). COSMIC: mining complete cancer genomes in the Catalogue of Somatic Mutations in Cancer Nucleic Acids Res. 39, D945-D950.

Fruman, D. A., and Rommel, C. (2011). PI3Kdelta inhibitors in cancer: rationale and serendipity merge in the clinic. Cancer Discov. 1, 562-572.

Galanis, E., Buckner, J. C., Maurer, M. J., Kreisberg, J. I., Ballman, K., Boni, J., Peralba, J. M., Jenkins, R. B., Dakhil, S. R., Morton, R. F., Jaeckle, K. A., Scheithauer, B. W., Dancey, J., Hidalgo, M., and Walsh, D. J. (2005). Phase II trial of temsirolimus (CCI-779) in recurrent glioblastoma multiforme: a North Central Cancer Treatment Group Study. J. Clin. Oncol. 23, 5294-5304.

Garg, K., Broaddus, R. R., Soslow, R. A., Urbauer, D. L., Levine, D. A., and Djordjevic, B. (2012). Pathologic scoring of PTEN immunohistochemistry in endometrial carcinoma is highly reproducible. Int. J. Gynecol. Pathol. 31, 48-56.

Garnett, M. J., Edelman, E. J., Heidorn, S. J., Greenman, C. D., Dastur, A., Lau, K. W., Greninger, P., Thompson, I. R., Luo, X., Soares, J., Liu, Q., Iorio, F., Surdez, D., Chen, L., Milano, R. J., Bignell, G. R., Tam, A. T., Davies, H., Stevenson, J. A., Barthorpe, S., Lutz, S. R., Kogera, F., Lawrence, K., Mclaren-Douglas, A., Mitropoulos, X., Mironenko, T., Thi, H., Richardson, L., Zhou, W., Jewitt, F., Zhang, T., O'Brien, P., Boisvert, J. L., Price, S., Hur, W., Yang, W., Deng, X., Butler, A., Choi, H. G., Chang, J. W., Baselga, J., Stamenkovic, I., Engelman, J. A., Sharma, S. V., Delattre, O., Saez-Rodriguez, J., Gray, N. S., Settleman, J., Futreal, P. A., Haber, D. A., Stratton, M. R., Ramaswamy, S., Mcdermott, U., and Benes, C. H. (2012). Systematic identification of genomic markers of drug sensitivity in cancer cells. Nature 483 , 570-575.

Gerlinger, M., Rowan, A. J., Horswell, S., Larkin, J., Endesfelder, D., Gronroos, E., Martinez, P., Matthews, N., Stewart, A., Tarpey, P., Varela, I., Phillimore, B., Begum, S., Mcdonald, N. Q., Butler, A., Jones, D., Raine, K., Latimer, C., Santos, C. R., Nohadani, M., Eklund, A. C., Spencer-Dene, B., Clark, G., Pickering, L., Stamp, G., Gore, M., Szallasi, Z., Downward, J., Futreal, P. A., and Swanton, C. (2012). Intratumor heterogeneity and branched evolution revealed by multiregion sequencing. N. Engl. J. Med. 366, 883-892.

Gerlinger, M., and Swanton, C. (2010). How Darwinian models inform therapeutic failure initiated by clonal heterogeneity in cancer medicine. Br. J. Cancer 103, 1139-1143.

Gewinner, C., Wang, Z. C., Richardson, A., Teruya-Feldstein, J., Etemadmoghadam, D., Bowtell, D., Barretina, J., Lin, W. M., Rameh, L., Salmena, L., Pandolfi, P. P., and Cantley, L. C. (2009). Evidence that inositol polyphosphate 4-phosphatase type II is a tumor suppressor that inhibits PI3K signaling. Cancer Cell $16,115-125$.

Gonzalez-Angulo, A. M., Ferrer-Lozano, J., Stemke-Hale, K., Sahin, A., Liu, S., Barrera, J. A., Burgues, O., Lluch, A. M., Chen, H., Hortobagyi, G. N., Mills, G. B., and Meric-Bernstam, F. (2011). PI3K pathway mutations and PTEN levels in primary and metastatic breast cancer. Mol. Cancer Ther. 10, 1093-1101.

Hardt, M., Chantaravisoot, N., and Tamanoi, F. (2011). Activating mutations of TOR (target of rapamycin). Genes Cells 16, 141-151.

Hollander, M. C., Blumenthal, G. M., and Dennis, P. A. (2011). PTEN loss in the continuum of common cancers, rare syndromes and mouse models. Nat. Rev. Cancer 11, 289-301.

Hudes, G., Carducci, M., Tomczak, P., Dutcher, J., Figlin, R., Kapoor, A., Staroslawska, E., Sosman, J., Mcdermott, D., Bodrogi, I., Kovacevic, Z., Lesovoy, V., Schmidt-Wolf, I. G., Barbarash, O., Gokmen, E., O’Toole, T., Lustgarten, S., Moore, L., and Motzer, R. J. (2007). Temsirolimus, interferon alfa, or both for advanced renal-cell carcinoma. N. Engl. J. Med. 356, 2271-2281.

Ihle, N. T., Lemos, R. Jr., Wipf, P., Yacoub, A., Mitchell, C., Siwak, D., Mills, G. B., Dent, P., Kirkpatrick, D. L., and Powis, G. (2009). Mutations in the phosphatidylinositol-3-kinase pathway predict for antitumor activity of the inhibitor PX-866 whereas oncogenic Ras is a dominant predictor for resistance. Cancer Res. 69, 143-150.

Iwenofu, O. H., Lackman, R. D., Staddon, A. P., Goodwin, D. G., Haupt, H. M., and Brooks, J. S. (2008). Phospho-S6 ribosomal protein: a potential new predictive sarcoma marker for targeted mTOR therapy. Mod. Pathol. 21, 231-237.

Jaiswal, B. S., Janakiraman, V., Kljavin, N. M., Chaudhuri, S., Stern, H. M., Wang, W., Kan, Z., Dbouk, H. A., Peters, B. A., Waring, P., Dela Vega, T., Kenski, D. M., Bowman,
K. K., Lorenzo, M., Li, H., Wu, J., Modrusan, Z., Stinson, J., Eby, M., Yue, P., Kaminker, J. S., De Sauvage, F. J., Backer, J. M., and Seshagiri, S. (2009). Somatic mutations in p85alpha promote tumorigenesis through class IA PI3K activation. Cancer Cell 16, 463-474.

Jamieson, S., Flanagan, J. U., Kolekar, S., Buchanan, C., Kendall, J. D., Lee, W. J., Rewcastle, G. W., Denny, W. A., Singh, R., Dickson, J., Baguley, B. C., and Shepherd, P. R. (2011) A drug targeting only p110alpha can block phosphoinositide 3-kinase signalling and tumor growth in certain cell types. Biochem. J. 438, 53-62.

Janku, F., Tsimberidou, A. M., GarridoLaguna, I., Wang, X., Luthra, R., Hong, D. S., Naing, A., Falchook, G. S., Moroney, J. W., Piha-Paul, S. A., Wheler, J. J., Moulder, S. L. Fu, S., and Kurzrock, R. (2011) PIK3CA mutations in patients with advanced cancers treated with PI3K/AKT/mTOR axis inhibitors. Mol. Cancer Ther. 10, 558-565.

Janku, F., Wheler, J. J., Westin, S. N. Moulder, S. L., Naing, A., Tsimberidou, A. M., Fu, S., Falchook, G. S., Hong, D. S., Garrido-Laguna, I., Luthra, R., Lee, J. J., Lu, K H., and Kurzrock, R. (2012). $\mathrm{PI} 3 \mathrm{~K} / \mathrm{AKT} / \mathrm{mTOR}$ inhibitors in patients with breast and gynecologic malignancies harboring PIK3CA mutations. J. Clin. Oncol. 30, 777-782.

Janne, P. A., Gray, N., and Settleman, J. (2009). Factors underlying sensitivity of cancers to small-molecule kinase inhibitors. Nat. Rev. Drug Discov. 8, 709-723.

Jia, S., Liu, Z., Zhang, S., Liu, P., Zhang, L., Lee, S. H., Zhang, J., Signoretti, S. Loda, M., Roberts, T. M., and Zhao, J. J. (2008). Essential roles of PI(3)Kpl10beta in cell growth, metabolism and tumorigenesis. Nature 454 776-779.

Jia, S., Roberts, T. M., and Zhao, J. J. (2009). Should individual PI3 kinase isoforms be targeted in cancer? Curr. Opin. Cell Biol. 21, 199-208.

Kalinsky, K., Jacks, L. M., Heguy, A., Patil, S., Drobnjak, M., Bhanot, U. K., Hedvat, C. V., Traina, T. A., Solit, D., Gerald, W., and Moynahan, M. E. (2009). PIK3CA mutation associates with improved outcome in breast cancer. Clin. Cancer Res. 15, 5049-5059.

Keedy, V. L., Temin, S., Somerfield, M. R., Beasley, M. B., Johnson, D. H., Mcshane, L. M., Milton, D. T., Strawn, J. R., Wakelee, H. A., and Giaccone, G. (2011). American Society of Clinical Oncology provisional clinical opinion: epidermal growth factor receptor (EGFR) Mutation testing for patients with advanced non-small-cell lung cancer considering first-line EGFR tyrosine kinase inhibitor therapy. J. Clin. Oncol. 29, 2121-2127.

Kim, W. Y., and Kaelin, W. G. (2004). Role of VHL gene mutation in human cancer. J. Clin. Oncol. 22, 4991-5004.

Lamming, D. W., Ye, L., Katajisto, P., Goncalves, M. D., Saitoh, M. Stevens, D. M., Davis, J. G., Salmon, A. B., Richardson, A., Ahima, R S., Guertin, D. A., Sabatini, D. M., and Baur, J. A. (2012). Rapamycininduced insulin resistance is mediated by mTORC2 loss and uncoupled from longevity. Science 335, 1638-1643

Laplante, M., and Sabatini, D. M. (2012). mTOR signaling in growth control and disease. Cell 149, 274-293.

Lehmann, B. D., Bauer, J. A., Chen, X., Sanders, M. E., Chakravarthy, A. B., Shyr, Y., and Pietenpol, J. A. (2011). Identification of human triple-negative breast cancer subtypes and preclinical models for selection of targeted therapies. $J$. Clin. Invest. 121, 2750-2767.

Linehan, W. M., Srinivasan, R., and Schmidt, L. S. (2010). The genetic basis of kidney cancer: a metabolic disease. Nat. Rev. Urol. 7, 277-285.

Liu, P., Cheng, H., Roberts, T. M., and Zhao, J. J. (2009). Targeting the phosphoinositide 3-kinase pathway in cancer. Nat. Rev. Drug Discov. 8, 627-644.

Loi, S., Haibe-Kains, B., Majjaj, S., Lallemand, F., Durbecq, V., Larsimont, D., Gonzalez-Angulo, A. M., Pusztai, L., Symmans, W. F., Bardelli, A., Ellis, P., Tutt, A. N., Gillett, C. E., Hennessy, B. T., Mills, G. B., Phillips, W. A., Piccart, M. J., Speed, T. P., Mcarthur, G. A., and Sotiriou, C. (2010). PIK3CA mutations associated with gene signature of low mTORC1 signaling and better outcomes in estrogen receptor-positive breast cancer. Proc. Natl. Acad. Sci. U.S.A. 107, 10208-10213.

Maira, S. M., Stauffer, F., Brueggen, J., Furet, P., Schnell, C., Fritsch, C., Brachmann, S., Chene, P., De Pover, A., Schoemaker, K., Fabbro, D., Gabriel, D., Simonen, M., Murphy, L., Finan, P., Sellers, W., and Garcia-Echeverria, C. (2008). Identification and characterization of NVP-BEZ235, a new orally available dual phosphatidylinositol 3-kinase/mammalian target of rapamycin inhibitor with potent 
in vivo antitumor activity. Mol. Cancer Ther. 7, 1851-1863.

Meric-Bernstam, F., Akcakanat, A., Chen, H., Do, K. A., Sangai, T., Adkins, F., Gonzalez-Angulo, A. M., Rashid, A., Crosby, K., Dong, M., Phan, A. T., Wolff, R. A., Gupta, S., Mills, G. B., and Yao, J. (2012). PIK3CA/PTEN mutations and Akt activation as markers of sensitivity to allosteric mTOR inhibitors. Clin. Cancer Res. 18, 1777-1789.

Meuillet, E. J., Zuohe, S., Lemos, R., Ihle, N., Kingston, J., Watkins, R., Moses, S. A., Zhang, S., Du-Cuny, L., Herbst, R., Jacoby, J. J., Zhou, L. L., Ahad, A. M., Mash, E. A., Kirkpatrick, D. L., and Powis, G. (2010). Molecular pharmacology and antitumor activity of PHT-427, a novel Akt/phosphatidylinositidedependent protein kinase 1 pleckstrin homology domain inhibitor. Mol. Cancer Ther. 9, 706-717.

Miller, T. W., Balko, J. M., and Arteaga, C. L. (2011). Phosphatidylinositol 3-kinase and antiestrogen resistance in breast cancer. J. Clin. Oncol. 29, 4452-4461.

Moroney, J. W., Schlumbrecht, M. P., Helgason, T., Coleman, R. L., Moulder, S., Naing, A., Bodurka, D. C., Janku, F., Hong, D. S., and Kurzrock, R. (2011). A phase I trial of liposomal doxorubicin, bevacizumab, and temsirolimus in patients with advanced gynecologic and breast malignancies. Clin. Cancer Res. 17, 6840-6846.

Neshat, M. S., Mellinghoff, I. K., Tran, C., Stiles, B., Thomas, G., Petersen, R., Frost, P., Gibbons, J. J., Wu, H., and Sawyers, C. L. (2001). Enhanced sensitivity of PTEN-deficient tumors to inhibition of FRAP/mTOR. Proc. Natl. Acad. Sci. U.S.A. 98, 10314-10319.

Ng, K. P., Hillmer, A. M., Chuah, C. T., Juan, W. C., Ko, T. K., Teo, A. S., Ariyaratne, P. N., Takahashi, N., Sawada, K., Fei, Y., Soh, S., Lee, W. H., Huang, J. W., Allen, J. C. Jr., Woo, X. Y., Nagarajan, N., Kumar, V., Thalamuthu, A., Poh, W. T., Ang, A. L., Mya, H. T., How, G. F., Yang, L. Y., Koh, L. P., Chowbay, B., Chang, C. T., Nadarajan, V. S., Chng, W. J., Than, H., Lim, L. C., Goh, Y. T., Zhang, S., Poh, D., Tan, P., Seet, J. E., Ang, M. K., Chau, N. M., Ng, Q. S., Tan, D. S., Soda, M., Isobe, K., Nothen, M. M., Wong, T. Y., Shahab, A., Ruan, X., Cacheux-Rataboul, V., Sung, W. K., Tan, E. H., Yatabe, Y., Mano, H., Soo, R. A., Chin, T. M., Lim, W. T., Ruan, Y., and Ong, S. T. (2012). A common
BIM deletion polymorphism mediates intrinsic resistance and inferior responses to tyrosine kinase inhibitors in cancer. Nat. Med. 18, 521-528.

Ni, J., Liu, Q., Xie, S., Carlson, C., Von, T., Vogel, K., Riddle, S., Benes, C., Eck, M., Roberts, T., Gray, N., and Zhao, J. (2012). Functional characterization of an isoform-selective inhibitor of PI3K-p110beta as a potential anticancer agent. Cancer Discov. 2, 425-433.

Noh, W. C., Mondesire, W. H., Peng, J., Jian, W., Zhang, H., Dong, J., Mills, G. B., Hung, M. C., and MericBernstam, F. (2004). Determinants of rapamycin sensitivity in breast cancer cells. Clin. Cancer Res. 10, 1013-1023.

O’Brien, C., Wallin, J. J., Sampath, D., Guhathakurta, D., Savage, H., Punnoose, E. A., Guan, J., Berry, L., Prior, W. W., Amler, L. C., Belvin, M., Friedman, L. S., and Lackner, M. R. (2010). Predictive biomarkers of sensitivity to the phosphatidylinositol $3^{\prime}$ kinase inhibitor GDC-0941 in breast cancer preclinical models. Clin. Cancer Res. 16, 3670-3683.

Pallis, A. G., Fennell, D. A., Szutowicz, E., Leighl, N. B., Greillier, L., and Dziadziuszko, R. (2011). Biomarkers of clinical benefit for antiepidermal growth factor receptor agents in patients with non-smallcell lung cancer. Br. J. Cancer 105, $1-8$.

Pinhel, I. F., Macneill, F. A., Hills, M. J., Salter, J., Detre, S., A'Hern, R., Nerurkar, A., Osin, P., Smith, I. E., and Dowsett, M. (2010). Extreme loss of immunoreactive p-Akt and $\mathrm{p}$-Erk1/2 during routine fixation of primary breast cancer. Breast Cancer Res. 12, R76.

Prahallad, A., Sun, C., Huang, S., Di Nicolantonio, F., Salazar, R., Zecchin, D., Beijersbergen, R. L., Bardelli, A., and Bernards, R. (2012). Unresponsiveness of colon cancer to BRAF(V600E) inhibition through feedback activation of EGFR. Nature 483, 100-103.

Sakr, R. A., Barbashina, V., Morrogh, M., Chandarlapaty, S., Andrade, V. P., Arroyo, C. D., Olvera, N., and King, T. A. (2010). Protocol for PTEN expression by immunohistochemistry in formalin-fixed paraffinembedded human breast carcinoma. Appl. Immunohistochem. Mol. Morphol. 18, 371-374.

Sanchez, C. G., Ma, C. X., Crowder, R. J., Guintoli, T., Phommaly, C., Gao, F., Lin, L., and Ellis, M. J. (2011). Preclinical modeling of combined phosphatidylinositol-3-kinase inhibition with endocrine therapy for estrogen receptor-positive breast cancer. Breast Cancer Res. 13, R21.

Santiskulvong, C., Konecny, G. E., Fekete, M., Chen, K. Y., Karam, A., Mulholland, D., Eng, C., Wu, H., Song, M., and Dorigo, O. (2011). Dual targeting of phosphoinositide 3-kinase and mammalian target of rapamycin using NVP-BEZ235 as a novel therapeutic approach in human ovarian carcinoma. Clin. Cancer Res. 17, 2373-2384.

Sarbassov, D. D., Ali, S. M., Sengupta, S., Sheen, J. H., Hsu, P. P., Bagley, A. F., Markhard, A. L., and Sabatini, D. M. (2006). Prolonged rapamycin treatment inhibits mTORC2 assembly and Akt/PKB. Mol. Cell 22, 159-168.

Sato, T., Nakashima, A., Guo, L., Coffman, K., and Tamanoi, F. (2010). Single amino-acid changes that confer constitutive activation of mTOR are discovered in human cancer. Oncogene 29, 2746-2752.

Serra, V., Markman, B., Scaltriti, M., Eichhorn, P. J., Valero, V., Guzman, M., Botero, M. L., Llonch, E., Atzori, F., Di Cosimo, S., Maira, M., GarciaEcheverria, C., Parra, J. L., Arribas, J., and Baselga, J. (2008). NVP-BEZ235, a dual PI3K/mTOR inhibitor, prevents PI3K signaling and inhibits the growth of cancer cells with activating PI3K mutations. Cancer Res. 68, 8022-8030.

Shah, S. P., Roth, A., Goya, R., Oloumi, A., Ha, G., Zhao, Y., Turashvili, G., Ding, J., Tse, K., Haffari, G., Bashashati, A., Prentice, L. M., Khattra, J., Burleigh, A., Yap, D., Bernard, V., Mcpherson, A., Shumansky, K., Crisan, A., Giuliany, R., HeraviMoussavi, A., Rosner, J., Lai, D., Birol, I., Varhol, R., Tam, A., Dhalla, N., Zeng, T., Ma, K., Chan, S. K., Griffith, M., Moradian, A., Cheng, S. W., Morin, G. B., Watson, P., Gelmon, K., Chia, S., Chin, S. F., Curtis, C., Rueda, O. M., Pharoah, P. D., Damaraju, S., Mackey, J., Hoon, K., Harkins, T., Tadigotla, V., Sigaroudinia, M. Gascard, P., Tlsty, T., Costello, J. F., Meyer, I. M., Eaves, C. J., Wasserman, W. W., Jones, S., Huntsman, D., Hirst, M., Caldas, C., Marra, M. A., and Aparicio, S. (2012). The clonal and mutational evolution spectrum of primary triple-negative breast cancers. Nature 486, 395-399.

Sharma, S. V., and Settleman, J. (2007). Oncogene addiction: setting the stage for molecularly targeted cancer therapy. Genes Dev. 21, 3214-3231.

She, Q. B., Chandarlapaty, S., Ye, Q., Lobo, J., Haskell, K. M., Leander, K. R., Defeo-Jones, D., Huber, H. E., and Rosen, N. (2008). Breast tumor cells with PI3K mutation or HER2 amplification are selectively addicted to Akt signaling. PLoS ONE 3, e3065. doi:10.1371/journal.pone.0003065

Shi, Y., Gera, J., Hu, L., Hsu, J. H., Bookstein, R., Li, W., and Lichtenstein, A. (2002). Enhanced sensitivity of multiple myeloma cells containing PTEN mutations to CCI-779. Cancer Res. 62, 5027-5034.

Sjodahl, G., Lauss, M., Gudjonsson, S., Liedberg, F., Hallden, C., Chebil, G., Mansson, W., Hoglund, M., and Lindgren, D. (2011). A systematic study of gene mutations in urothelial carcinoma; inactivating mutations in TSC2 and PIK3R1. PLoS ONE 6, e18583. doi:10.1371/journal.pone.0018583

Soria, J. C., Shepherd, F. A., Douillard, J. Y., Wolf, J., Giaccone, G., Crino, L., Cappuzzo, F., Sharma, S., Gross, S. H., Dimitrijevic, S., Di Scala, L., Gardner, H., Nogova, L., and Papadimitrakopoulou, V. (2009). Efficacy of everolimus (RAD001) in patients with advanced NSCLC previously treated with chemotherapy alone or with chemotherapy and EGFR inhibitors. Ann. Oncol. 20, 1674-1681.

Stemke-Hale, K., Gonzalez-Angulo, A. M., Lluch, A., Neve, R. M., Kuo, W. L., Davies, M., Carey, M., Hu, Z., Guan, Y., Sahin, A., Symmans, W. F., Pusztai, L., Nolden, L. K., Horlings, H., Berns, K., Hung, M. C., Van De Vijver, M. J., Valero, V., Gray, J. W., Bernards, R., Mills, G. B., and Hennessy, B. T. (2008). An integrative genomic and proteomic analysis of PIK3CA, PTEN, and AKT mutations in breast cancer. Cancer Res. 68, 6084-6091.

Stern, H. M. (2012). Improving treatment of HER2-positive cancers: opportunities and challenges. Sci. Transl. Med. 4, 127rv122.

Tabernero, J., Rojo, F., Calvo, E., Burris, H., Judson, I., Hazell, K., Martinelli, E., Ramon Y Cajal, S., Jones, S., Vidal, L., Shand, N., Macarulla, T., Ramos, F. J., Dimitrijevic, S., Zoellner, U., Tang, P., Stumm, M., Lane H. A., Lebwohl, D., and Baselga, J. (2008). Dose- and scheduledependent inhibition of the mammalian target of rapamycin pathway with everolimus: a phase I tumor pharmacodynamic study in patients with advanced solid tumors. J. Clin. Oncol. 26, 1603-1610.

Tanaka, H., Yoshida, M., Tanimura, H., Fujii, T., Sakata, K., Tachibana, Y., Ohwada, J., Ebiike, H., Kuramoto, S., Morita, K., Yoshimura, Y., Yamazaki, T., Ishii, N., Kondoh, O., and Aoki, Y. (2011). The selective class I 
PI3K inhibitor CH5132799 targets human cancers harboring oncogenic PIK3CA mutations. Clin. Cancer Res. 17, 3272-3281.

Tarhini, A., Kotsakis, A., Gooding, W., Shuai, Y., Petro, D., Friedland, D., Belani, C. P., Dacic, S., and Argiris, A. (2010). Phase II study of everolimus (RAD001) in previously treated small cell lung cancer. Clin. Cancer Res. 16, 5900-5907.

Thomas, G. V., Tran, C., Mellinghoff, I. K., Welsbie, D. S., Chan, E., Fueger, B., Czernin, J., and Sawyers, C. L. (2006). Hypoxia-inducible factor determines sensitivity to inhibitors of mTOR in kidney cancer. Nat. Med. 12, 122-127.

Turner, N. C., and Reis-Filho, J. S. (2012). Genetic heterogeneity and cancer drug resistance. Lancet Oncol. 13, e178-e185.

Tzenaki, N., Andreou, M., Stratigi, K., Vergetaki, A., Makrigiannakis, A., Vanhaesebroeck, B., and Papakonstanti, E. A. (2012). High levels of p110delta PI3K expression in solid tumor cells suppress PTEN activity, generating cellular sensitivity to p110delta inhibitors through PTEN activation. FASEB J. 26, 2498-2508.

Urick, M. E., Rudd, M. L., Godwin, A. K., Sgroi, D., Merino, M., and Bell, D. W. (2011). PIK3R1 (p85alpha) is somatically mutated at high frequency in primary endometrial cancer. Cancer Res. 71, 4061-4067.

van der Heijden, M. S., and Bernards, R. (2010). Inhibition of the PI3K pathway: hope we can believe in? Clin. Cancer Res. 16, 3094-3099.
Vanhaesebroeck, B., GuillermetGuibert, J., Graupera, M., and Bilanges, B. (2010). The emerging mechanisms of isoform-specific PI3K signalling. Nat. Rev. Mol. Cell Biol. 11, 329-341.

Vasudevan, K. M., Barbie, D. A., Davies, M. A., Rabinovsky, R., Mcnear, C. J., Kim, J. J., Hennessy, B. T., Tseng, H., Pochanard, P., Kim, S. Y., Dunn, I. F., Schinzel, A. C., Sandy, P., Hoersch, S., Sheng, Q., Gupta, P. B., Boehm, J. S., Reiling, J. H., Silver, S., Lu, Y., Stemke-Hale, K., Dutta, B., Joy, C., Sahin, A. A., GonzalezAngulo, A. M., Lluch, A., Rameh, L. E., Jacks, T., Root, D. E., Lander, E. S., Mills, G. B., Hahn, W. C., Sellers, W. R., and Garraway, L. A. (2009). AKT-independent signaling downstream of oncogenic PIK3CA mutations in human cancer. Cancer Cell $16,21-32$.

Velickovic, M., Delahunt, B., Mciver, B. and Grebe, S. K. (2002). Intragenic PTEN/MMAC1 loss of heterozygosity in conventional (clear-cell) renal cell carcinoma is associated with poor patient prognosis. Mod. Pathol. 15, 479-485.

Wee, S., Wiederschain, D., Maira, S. M., Loo, A., Miller, C., Debeaumont, R., Stegmeier, F., Yao, Y. M., and Lengauer, C. (2008) PTEN-deficient cancers depend on PIK3CB. Proc. Natl. Acad. Sci. U.S.A. 105, 13057-13062.

Weigelt, B., Pusztai, L., Ashworth, A., and Reis-Filho, J. S. (2012). Challenges translating breast cancer gene signatures into the clinic. Nat. Rev. Clin. Oncol. 9, 58-64.
Weigelt, B., Warne, P. H., and Downward, J. (2011). PIK3CA mutation, but not PTEN loss of function, determines the sensitivity of breast cancer cells to mTOR inhibitory drugs. Oncogene 30, 3222-3233.

Weinstein, I. B. (2002). Cancer. Addiction to oncogenes - the Achilles heal of cancer. Science 297, 63-64.

Wu, R., Hu, T. C., Rehemtulla, A., Fearon, E. R., and Cho, K. R. (2011). Preclinical testing of PI3K/AKT $/ \mathrm{mTOR}$ signaling inhibitors in a mouse model of ovarian endometrioid adenocarcinoma. Clin. Cancer Res. 17 7359-7372.

Yang, L., Clarke, M. J., Carlson, B. L., Mladek, A. C., Schroeder, M. A., Decker, P., Wu, W., Kitange, G. J., Grogan, P. T., Goble, J. M., Uhm, J., Galanis, E., Giannini, C., Lane, H. A., James, C. D., and Sarkaria, J. N. (2008). PTEN loss does not predict for response to RAD001 (Everolimus) in a glioblastoma orthotopic xenograft test panel. Clin. Cancer Res. 14 3993-4001.

Yap, T. A., Gerlinger, M., Futreal, P. A., Pusztai, L., and Swanton, C. (2012). Intratumor heterogeneity: seeing the wood for the trees. Sci. Transl. Med. 4, 127ps110.

Yu, K., Toral-Barza, L., Shi, C., Zhang, W. G., Lucas, J., Shor, B., Kim, J., Verheijen, J., Curran, K., Malwitz, D. J., Cole, D. C., Ellingboe, J., AyralKaloustian, S., Mansour, T. S., Gibbons, J. J., Abraham, R. T., Nowak, P., and Zask, A. (2009). Biochemical, cellular, and in vivo activity of novel ATP-competitive and selective inhibitors of the mammalian target of rapamycin. Cancer Res. 69, 6232-6240.

Yu, K., Toral-Barza, L., Shi, C., Zhang, W. G., and Zask, A. (2008). Response and determinants of cancer cell susceptibility to PI3K inhibitors: combined targeting of PI3K and Mek1 as an effective anticancer strategy. Cancer Biol. Ther. 7, 307-315.

Zhang, S., and Yu, D. (2010). PI(3)king apart PTEN's role in cancer. Clin. Cancer Res. 16, 4325-4330.

Conflict of Interest Statement: The authors declare that the research was conducted in the absence of any commercial or financial relationships that could be construed as a potential conflict of interest.

Received: 21 June 2012; accepted: 14 August 2012; published online: 31 August 2012.

Citation: Weigelt $B$ and Downward $J$ (2012) Genomic determinants of PI3K pathway inhibitor response in cancer. Front. Oncol. 2:109. doi: 10.3389/fonc.2012.00109

This article was submitted to Frontiers in Molecular and Cellular Oncology, a specialty of Frontiers in Oncology. Copyright (c) 2012 Weigelt and Downward. This is an open-access article distributed under the terms of the Creative Commons Attribution License, which permits use, distribution and reproduction in other forums, provided the original authors and source are credited and subject to any copyright notices concerning any third-party graphics etc. 